\title{
NEOTECTONICS, RIVER CAPTURE AND LANDSCAPE EVOLUTION IN THE HIGHLANDS OF SE BRAZIL
}

neotectônica, capturas fluviais e evolução do relevo nas terras altas do SE do Brasil

\author{
Chrystiann Lavarini * \\ Antônio Pereira Magalhães Júnior ** \\ Fábio Soares de Oliveira *** \\ Alex de Carvalho $* * * *$
}

\begin{abstract}
Resumo
O Sinclinal Moeda, localizado nas terras altas do Quadrilátero Ferrífero (SE do Brasil), se insere em um ambiente de inversão do relevo e de reorganização da drenagem. Neste trabalho foram analisadas as bacias do Rio do Peixe e Ribeirão Mata Porcos, que drenam o Sinclinal. Foram realizados procedimentos de análise morfológica e morfométrica em geoprocessamento. Os resultados indicam que o Ribeirão Mata Porcos teria sido capturado primeiro, permitindo o avanço da onda de incisão que denudou a bacia e rebaixou o nível de base. Em uma última fase de capturas, teria ocorrido a reversão da drenagem de alguns canais e a geração de cotovelos. Ao longo destes eventos ocorreu a migração preferencial dos canais fluviais em direção a leste e o pirateamento de águas subsuperficiais e a decapitação (beheading) de parte da bacia do Rio do Peixe. Baseado nestas análises e em dados da literatura, acredita-se que os eventos geomorfológicos responsáveis pela evolução do Sinclinal Moeda durante o Quaternário estiveram associados, sobretudo, a capturas fluviais (sensu strictu, diversion e beheading) controladas por causas neotectônicas e litoestruturais.
\end{abstract}

Palavras-chave: Quadrilátero Ferrífero; Sinclinal Moeda; Ribeirão Mata Porcos; Rio do Peixe; Rio das Velhas

\begin{abstract}
The Moeda syncline, located in the highlands of the Iron Quadrangle mountains (SE Brazil), is a setting of relief inversion and drainage reorganization. In this work, we investigate the Rio do Peixe and Ribeirão Mata Porcos watersheds from this syncline. Morphological and morphometric analyses were carried out on GIS environment. The results indicate that the Ribeirão Mata Porcos watershed was captured first, allowing a wave of incision propagation that denuded the watershed and lowered the base level. During the last phase of river capture, drainage reversal and elbows of capture developed in certain channels. During these events, there was a preferential migration of river channels to the east, groundwater piracy and beheading of the Rio do Peixe's area. Based on such results, we believe that the events responsible for the landscape evolution of the Moeda syncline during the Quaternary were particularly those associated with river capture (sensu strictu, diversion and beheading) driven by both neotectonics and litho-structural influences.
\end{abstract}

Key words: Iron Quadrangle; Moeda Syncline; Mata Porcos river; Peixe river; Velhas river.

\section{Resumen}

El Sinclinal Moeda, ubicado en las tierras altas del Cuadrilátero Ferrífero (sureste de Brasil), presenta características de inversión de relieve y reorganización de drenaje. En este trabajo, las cuencas del Rio do Peixe y Ribeirão Mata Porcos fueron analizados. Se llevaron a cabo análisis morfológico y morfométrico por medio de SIG. Los resultados indican que el Ribeirão Mata Porcos ha sido capturado primero, permitiendo el avance de la onda de incisión que denudó la cuenca y rebajó el nivel de base. En una última fase de las capturas, se han producido la reversión de algunos canales de drenaje y la generación de codos fluviales. A lo largo de estos hechos ocurrieron la migración preferente de canales fluviales para la dirección este, el pirateamento de las aguas del subsuelo y la decapitación de parte de la cuenca del Rio do Peixe. Basándose en estos resultados, se cree que los eventos responsables por la evolución del Sinclinal Moeda durante el Cuaternario estaban relacionados, sobretodo a las capturas fluviales (sensu strictu, diversion y beheading) controlado por causas neotectónicas y litoestructurales.

Palabras-clave: Cuadrilátero Ferrífero; Sinclinale Moeda; Río Mata Porcos; Río del Peixe; Río de las Velhas.

(*) Phd Student University of Edinburgh, School of GeoSciences - James Hutton Road, Edinburgh, EH93FE, Edinburgh, GrãBretanha. Tel: (44) 13165059 - lavarini.c@gmail.com

(**) Lecturer, Phd Federal University of Minas Gerais (Universidade Federal de Minas Gerais) - Av. Antônio Carlos 6627, CEP: 31270901, Belo Horizonte, (MG), Brasil. Tel: (+55 31) 34095462 - magalhaesufmg@yahoo.com.br

(***) Phd Federal University of Minas Gerais (Universidade Federal de Minas Gerais) - Av. Antônio Carlos 6627, CEP: 31270901, Belo Horizonte, (MG), Brasil. Tel: (+55 31) 34095422 - fabiosolos@gmail.com

(****) Phd Student Federal University of Minas Gerais (Universidade Federal de Minas Gerais) - AAv. Antônio Carlos 6627, CEP: 31270901, Belo Horizonte, (MG), Brasil. Tel: (+55 31) 34095462 - alexrochacarvalho@gmail.com 


\section{INTRODUCTION}

Since the beginning of geomorphological research, phenomena such as river capture, drainage expansion and relief inversion have been important to our understanding of long-term landform evolution (DAVIS, 1890; 1899; BOWMAN, 1904). More recently, many researchers have recognized the influence of tectonic activity and river capture, acting either together or individually, in drainage reorganization (CALVACHE AND VISERAS, 1997; WENZENS AND WENZENS, 1997; MATHER, 2000; ÁNTON et al., 2013).

Bishop (1995) summarized the processes responsible for river capture and divided them into three categories: (i) river capture sensu strictu; (ii) river diversion and (iii) beheading. The first represents the capture of one river by another one of lower elevation due to aggressive headward erosion. A general method for identifying captures has been to identify drainage elbows, knickpoints and wind gaps. The second, river diversion, can be understood as similar to river capture, but, unlike the former process, the river is forced to flow into another watershed by channel migration, tectonic tilting or catastrophic processes. The third process, beheading, refers to the appropriation of the catchment area drained by another river without maintaining the same drainage direction and/or without the presence of river elbows.

Synthesizing the knowledge of river captures, several authors assert that, beyond the evidence from the geological record, such as floodplains and river terraces, morphological evidence is one of the best types of evidence for studying river capture (SMALL, 1978; MATHER, 2000; STOKES et al, 2002). Associated with this fact, advances in geologic software has led to considerable increases in the application of GIS methods for understanding drainage network evolution and, thus, landform evolution (WALSH, 1998; ATTAL et al., 2008).

In landforms controlled by synclinal and anticlinal megafolds, aside from the evidence and phenomena of river capture, landforms such as water gaps have played a major role in the interpretation of regional evolution (CLARK, 1989; SUMMERFIELD, 1991; TWIDALE, 2004). In many cases, water gaps have been identified as morphological evidence of relief inversion (TWIDALE, 1976; CHORLEY et al., 1984).

Our study was aimed at gathering morphological and morphometric information regarding the long-term geomorphological changes in the area underlain by the Moeda syncline, located in the Quadrilátero Ferrífero (Iron Quadrangle) region of southeastern Brazil.

During the Neoproterozoic, several compressional events generated broad fold structures, including megasynclines and megaanticlines (CHEMALE JR. et al., 1994; SILVA, 1999). Later, the Quadrilátero Ferrífero and the Moeda syncline were subjected to a long period of denudation and neotectonic events (SAADI, 1991; MAGALHÃES JÚNIOR, 1993; MAGALHÃES JÚNIOR et al., 2012) which produced a relief inversion, a drainage reorganization and the sculpture of water gaps (BARBOSA, 1949; KING, 1956; DORR, 1969). Due to these conditions, the Moeda syncline is a highly appropriate area for studies of landform evolution and river capture. In addition, the region is located in the largest zone of iron ore production in Brazil and in the world (SPIER et al., 2003).

\section{STUDY AREA}

\section{PLACEMENT OF THE INVESTIGATED WATERSHEDS}

The Moeda syncline is situated on the west edge of the megafeature known as Quadrilátero Ferrifero, in the continental section of southeastern Brazil (Figure 1). The Moeda syncline is drained by two main drainage basins: in the south by the Ribeirão Mata Porcos watershed and in the north by the Rio do Peixe watershed. Both of these are tributaries of the Rio das Velhas, which is also a tributary of the Rio São Francisco, one of the most important rivers in Brazil. 


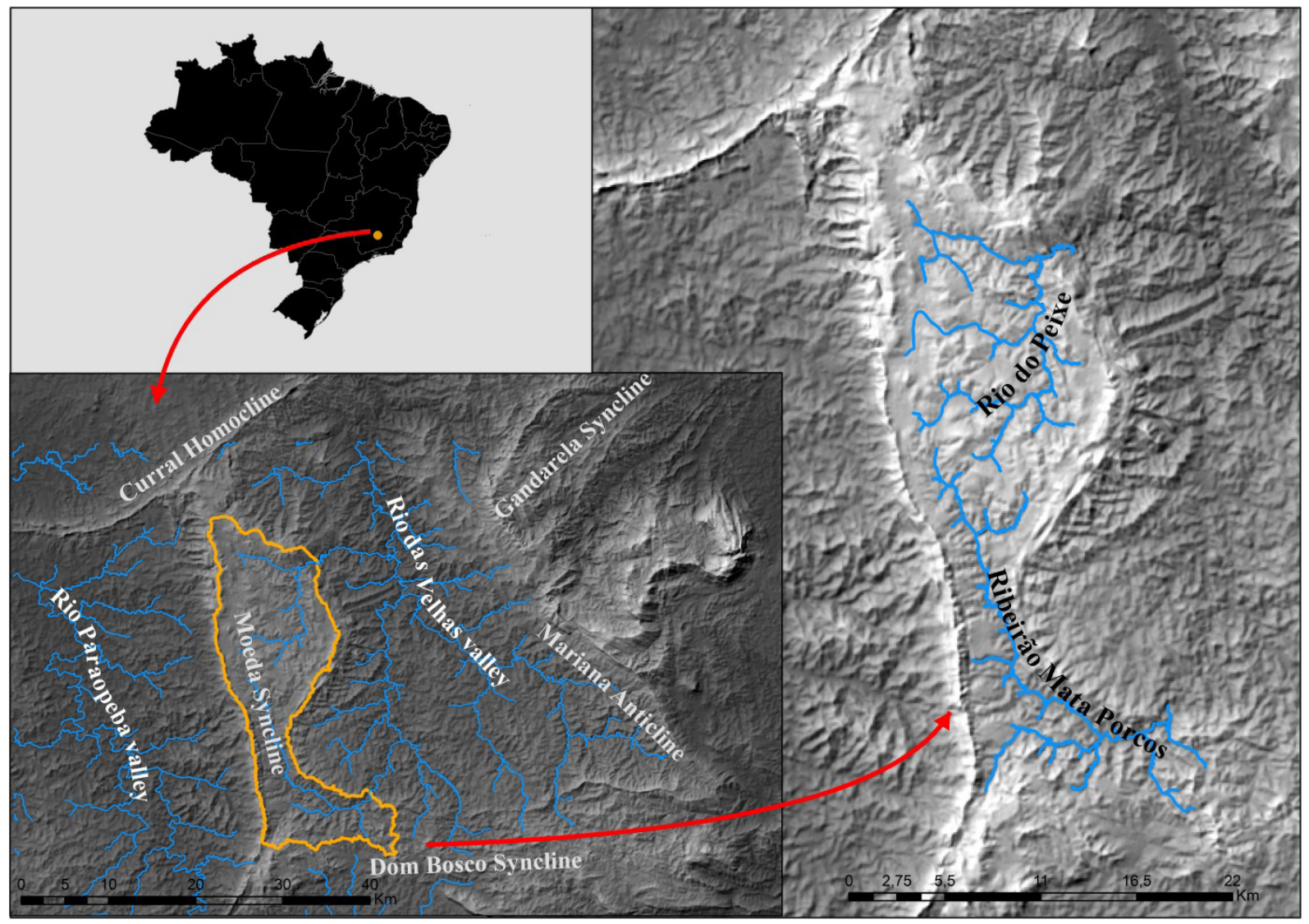

Figure 1 - The Moeda syncline's watersheds and geomorphological setting of the Quadrilátero Ferrífero containing its primary features. The north edge is defined by the Curral homocline, the east flank is defined by the Gandarela syncline, the west edge is the Moeda syncline and the south is defined by the Dom Bosco syncline.

The general drainage pattern of the Ribeirão Mata Porcos watershed is dendritic, with certain segments displaying a parallel pattern on the west edge of the Moeda syncline. The study area consists of approximately $163 \mathrm{~km}^{2}$ of drainage basin. Unlike all other rivers in the region, the SSE orientation upstream of the water gap on the syncline's east flank makes the Ribeirão Mata Porcos unique.

The Rio do Peixe valley flows east in its upper course, changing abruptly to a N-S orientation in the upper-middle course. This river then flows northeast near the water gap. The study area has an area of approximately $177 \mathrm{~km}^{2}$, a dendritic drainage pattern and several segments with anomalous inflections.

As the primary focus of this study was the geomorphological evolution of the Moeda syncline, the river segments adopted in this study were limited to those of the syncline's borders, and therefore other areas of the Quadrilátero Ferrífero were not investigated.

\section{REGIONAL GEOLOGIC SETTING}

The area of the Moeda syncline, which fully contains the analyzed watersheds, is approximately $40 \mathrm{~km}$ long north to south and is on the west side of the Quadrilátero Ferrífero. This syncline is in contact with the Bomfim Metamorphic Complex on the west, the Bação Metamorphic Complex on the east and the Serra do Curral homocline on the north.

The Moeda syncline has affected nearly all of the supracrustal units of the Quadrilátero Ferrífero, which primarily consist of the Rio das Velhas Supergroup at the bottom and the Minas Supergroup (Itabira and Piracicaba Groups) at the top. (Figure 2) (SILVA; GOMES, 2001). 


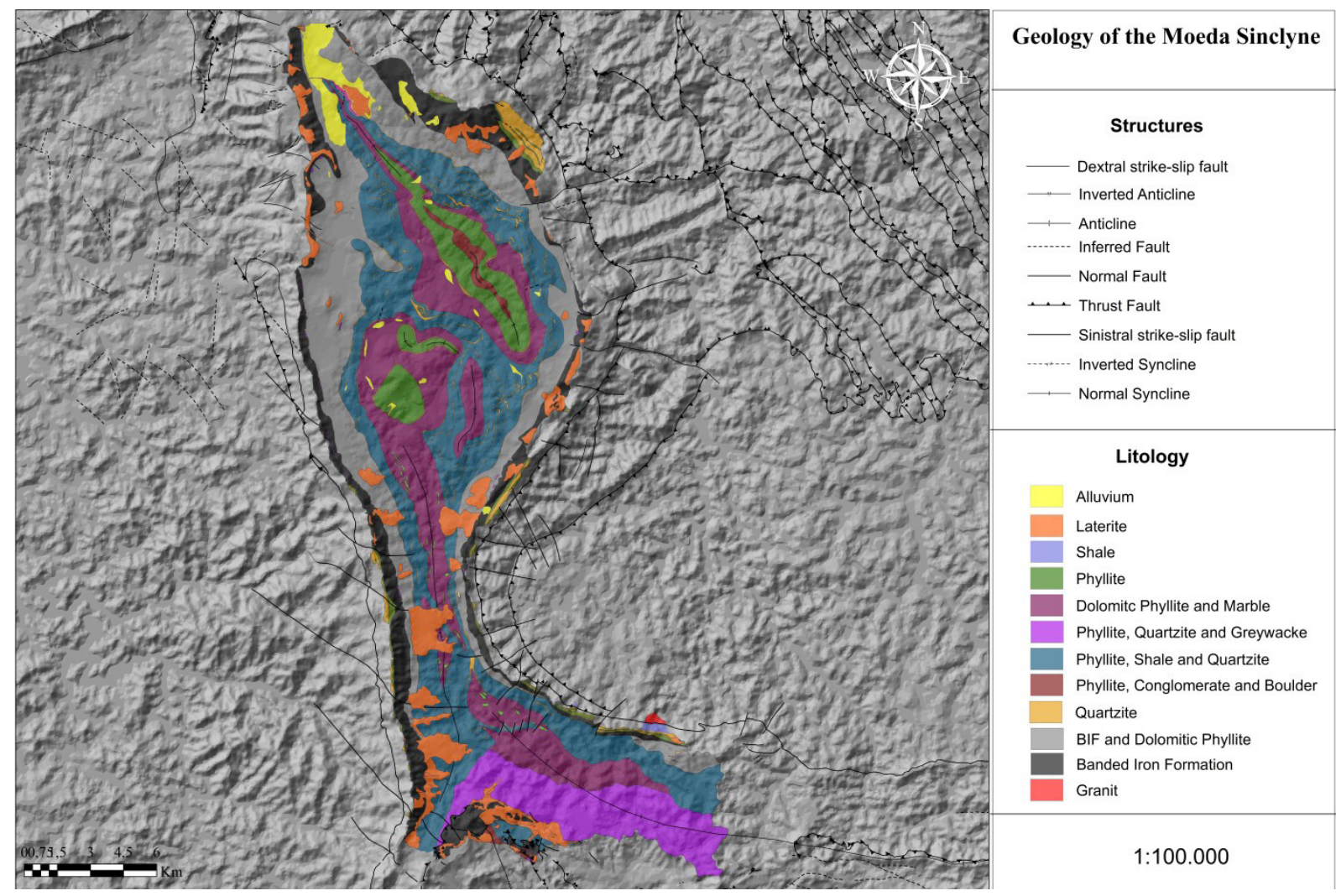

Figure 2 - Lithological units of the Moeda syncline. Shale of the Rio das Velhas Supergroup is exposed in a small area near the Ribeirão Mata Porcos' outlet. The majority of the area is underlain by the Minas Supergroup, which is Paleoproterozoic (phyllite, BIF, quartzite, shale and marble). Cenozoic materials are exposed in certain areas (alluvium and laterites).

The Moeda syncline's west flank dips between $40^{\circ}$ and $50^{\circ}$ to the east. It is affected by NW-SE strike-slip faults with sinistral and dextral displacements of hundreds of meters. The west flank is also affected by the Moeda-Bonfim shear zone, which is a deep tectonic structure generated by extensional movements and west-verging reverse faults (SILVA, 1999).

The dips of the east flank vary considerably: more than $45^{\circ}$ on the north side, approximately the median value $\left(40^{\circ}-45^{\circ}\right)$ on the west edge and lower angles $\left(<25^{\circ}\right)$ in the southwest portion (SILVA, 1999; CHEMALE JR. et al., 1994).

Proterozoic geotectonic events on the west edge were responsible for the lateral migration of softer rocks of the Rio das Velhas Supergroup by transpressive deformation (Dorr, 1969). This process has created a convex morphology of the east flank in plain view, with west-verging polarity and inverted stratigraphy (GOMES et al., 2005; DORR, 1969).

Along the west edge of the syncline, the Precambrian tectonic strains generated the inverse reactivation of the originally normal faults of the Moeda-Bonfim shear zone (GOMES et al., 2005; CHEMALE JR. et al., 1991).

\section{CENOZOIC EVOLUTION OF THE MOEDA SYNCLINE}

During the Quaternary, a range of geomorphological records indicate a substantial increase in the number of river capture events in the Quadrilátero Ferrífero, the captures of the Ribeirão Mata Porcos and Rio do Peixe being the most prominent (BARBOSA, 1949; KING, 1956; DORR, 1969). The morphological evidence of these captures is preserved in two water gaps on the east side, specifically, along the border between the Moeda syncline and the Bação Complex. (Figure 3 ).

According to Barbosa (1949) and confirmed by Barbosa and Rodrigues (1965), the paleodrainage was predominantly endoreic in the upper course before the river captures controlled by the Rio das Velhas enabled outflow from the syncline. There was flow in the middle course oriented toward the Bação Complex, but without flow to areas outside the syncline. 


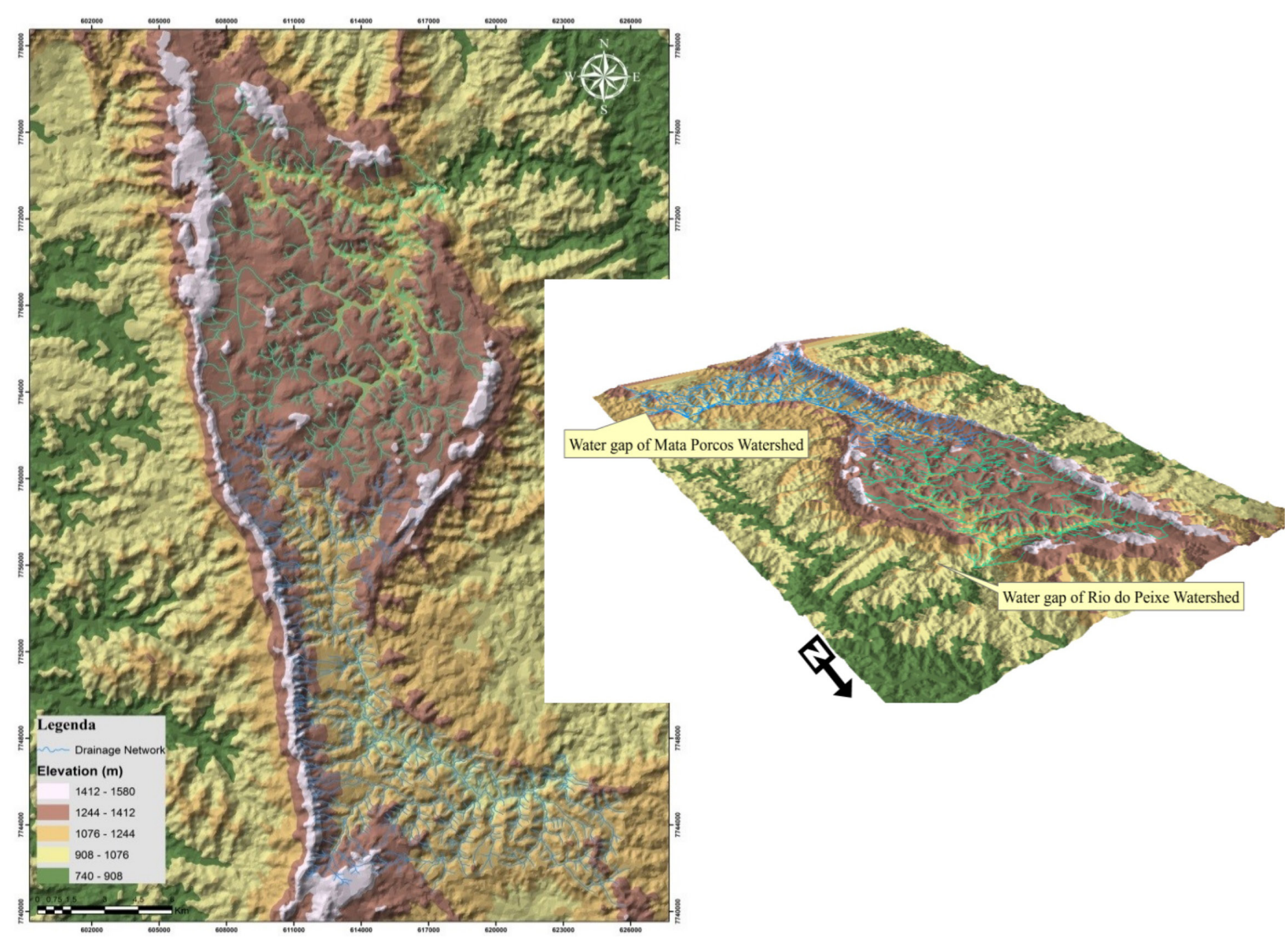

Figure 3 - On the left, the morphology of the Moeda syncline. On the right, the location of the water gaps where the drainage basins flow to the Rio das Velhas.

In contrast, King (1956) conjectured and Dorr (1969) confirmed that in the south part of the syncline, the Ribeirão Mata Porcos was originally drained by the Rio Paraopeba to the west, and only after a post-Pliocene denudational cycle was it captured by the Rio das Velhas to the east.

\section{MATERIAL AND METHODS}

A range of procedures cited in the scientific literature were adopted to reconstruct the Moeda syncline's geomorphologic history. Specifically, a set of (i) morphological and (ii) morphometric analyses was performed.

In the first method (i), morphological evidence, such as drainage inflections (elbows) and changes in drainage orientation, were sought. In the second (ii), the drainage density (Dd), relief ratio $(\mathrm{Rr})$, hypsometric integral (HI), hypsometric curve (HC), stream length-gradient index (SL), asymmetry factor (AF), transverse topographic symmetry factor $(\mathrm{T})$, volume of sediments removed from the watersheds and landform downwearing were measured.

The morphological and morphometric methods were performed using the ArcGIS 10.1 software program and cartographic bases provided by the Instituto Mineiro de Gestão das Águas (IGAM), Serviço Geológico do Brasil (CPRM), Instituto Brasileiro de Geografia e Estatística (IBGE) and STRM images provided by the Instituto Nacional de Pesquisas Espaciais (INPE). All of our methods are described in detail below.

\section{METHODS OF MORPHOLOGICAL ANALYSIS}

Qualitative analysis of the landforms was performed through the observation of the stream network and preparation of transverse topographic profiles of the Ribeirão Mata Porcos and Rio do 
Peixe fluvial valleys. In addition, the neighboring watersheds of the Moeda syncline were analyzed due to the possibility of drainage reorganization and river captures of these watersheds during the Quaternary.

\section{METHODS OF MORPHOMETRIC ANALYSIS}

The drainage density (Dd) is given by the equation

$$
\mathrm{Dd}=\mathrm{Lt} / \mathrm{A}
$$

where Lt represents the sum of the lengths of all rivers in a watershed, and A is the drainage area. This parameter expresses the extent of hydrologic behavior controlled by the lithology and structures and reflects the infiltration capacity and degree of channel initiation (CHRISTOFOLETTI, 1979).

The relief ratio (Rr), first described by Schumm (1956), is given by the equation

$$
\mathrm{Rr}=\Delta \mathrm{Hm} / \mathrm{Lp}
$$

where $\Delta \mathrm{Hm}$ represents the maximum relief, and Lp is the length of the main channel.

This index allows for an understanding of the elevation changes as a function of variations in the channel length. The larger this value, the greater the relief between the headwater and the outlet and, hence, the greater the watershed's mean slope.

The hypsometric curves (HCs) are obtained using scatter plots in which the cumulative area of the height intervals and cumulative relief are plotted along the abscissa and ordinate, respectively. The differences in the curves' shapes are related to the degree of disequilibrium in the balance between erosional and tectonic forces: convex curves indicate a more stable watershed, and concave curves indicate a greater role of erosional processes (WEISSEL et al., 1994; HURTREZ et al., 1999).

The hypsometric integral (HI) is an estimation similar to the hypsometric curve and allows for an evaluation of the correspondence between the landforms and the Davisian cycle of erosion (Strahler, 1952). In the "old" stage, the drainage basin is fully graded ( $\mathrm{HI}<0.3)$, whereas in the "maturity" $(0.3<\mathrm{HI}<0.6)$ and "youth" stages $(\mathrm{HI}>0.6)$, the susceptibility to erosion is higher (Sarangi et al., 2001).

The $\mathrm{HI}$ is calculated using the equation

$$
\mathrm{HI}=[(\text { Emean }- \text { Emin })) /((\text { EMax }- \text { Emin })]
$$

where Emean corresponds to the mean elevation, Emin to the minimum elevation and Emax to the maximum elevation in the watershed.

The stream length-gradient index (SL), defined by Hack (1973), may be mathematically described in two ways. In one version, the index SLseg corresponds to specific river segments, and in the second, the index SLtotal corresponds to the total stream length (ETCHEBEHERE et al., 2004).

The index SLseg can be obtained using the equation

$$
\operatorname{SLseg}=\Delta \mathrm{H} /(\Delta \mathrm{L} * \mathrm{~L})
$$

The index SLtotal can be obtained using the equation

$$
\text { SLtotal }=\Delta \mathrm{H} /(\ln * \mathrm{~L})
$$

where $\Delta H$ represents the channel or segment relief, $\ln$ is the natural logarithm, $\mathrm{L}$ is the total stream length, and $\Delta \mathrm{L}$ is the length of the analyzed segment. 
According to Etchebehere et al. (2004), the SL indexes described above are used to evaluate the sensitivity of changes in the river's slope. Such changes may be associated with many factors, such as (i) the outfall of tributaries with high flow, (ii) changes in the lithological resistance and (iii) neotectonic activity.

To verify the influence of the mentioned causal variables (tributaries, neotectonics and lithology), the anomaly criteria proposed by Seeber and Gornitz (1983) were used. According to these authors, an SLseg/SLtotal ratio equal to 2 represents the first anomaly range values, designated 2nd-order anomalies, ratios above 10 represent anomalies of the 1 st order, and results below 2 represent nonanomalous stream segments.

To verify the drainage network assymetry and its likely causes, the assymetry factor (AF) and transverse topographic symmetry factor $(\mathrm{T})$ were calculated.

The assymetry factor (AF), proposed by Hare and Gardner (1985), measures the displacement of the watershed axis relative to its midline. This factor can be obtained using the equation

$$
\mathrm{AF}=100 *(\mathrm{Ar} / \mathrm{At})
$$

where Ar is the main channel's right margin area, and At represents the total drainage area of the watershed.

The transverse topographic symmetry factor $(\mathrm{T})$ is a more sophisticated quantitative index, developed by Cox (1994), that allows for an evaluation of the asymmetry of river channels in a drainage basin and the manner in which this asymmetry varies with length. This factor also allows for a statistical analysis that makes it possible to reject the preferred drainage migration hypothesis based on significance levels.

Thus, all river segments of the Ribeirão Mata Porcos and Rio do Peixe watersheds measuring 2 $\mathrm{km}$ or longer were divided into segments 500 meters long, where the measurements were performed. The transverse topographic symmetry factor $(\mathrm{T})$ can be obtained using the equation

$$
\mathrm{T}=\mathrm{Da} / \mathrm{Dd}
$$

where Da represents the distance between the drainage basin's midline and the active meander, and Dd is the distance between the drainage basin's midline and the drainage divide.

In association with these exploratory mathematical techniques, Cox (1994) proposed the use of a statistical procedure developed by Curray (1956). Cox (1994) calculated the probability of a $\mathrm{T}$ vector from its origins in random combinations rather than preferred ones as occur with channel migrations due to external causes. This probability (p) can be calculated using the equation

$$
p=e^{\left(-L^{2} n\right)\left(10^{-4}\right)}
$$

where $\mathrm{e}$ is the base of the natural logarithm, $\mathrm{L}$ is the mean magnitude vector and $\mathrm{n}$ represents the number of analyzed river segments.

Finally, the volume of sediments removed from the drainage basins was estimated based on the difference between a theoretical paleosurface, referring to a time before the relief inversion, and the current surface. This paleosurface was generated based on the heights of the east and west divides, which constitute the syncline's edges. Then, from the height values of the paleo- and current surface, the mean downwearing of the landform was calculated. 


\section{RESULTS}

\section{TOPOGRAPHIC PROFILES AND MORPHOLOGICAL PATTERNS}

The data obtained from the Moeda syncline reveal distinct morphological patterns in the main watersheds under investigation.

The drainage area of the Rio do Peixe displays nearly twice the area of straight hillslopes compared to the Ribeirão Mata Porcos watershed (Table 1). Likewise, the Rio do Peixe watershed contains nearly seven times more segments of smooth slope and three times more moderate slope areas (Table 2).

Table 1 - Percentage of slope classes existing in the investigated watersheds

\begin{tabular}{c|c|c}
\hline Slope Classes & Ribeirão Mata Porcos & Rio do Peixe \\
\hline Slight* $^{*}$ & 0.0 & 0.2 \\
\hline Moderate $^{* *}$ & 6.0 & 18.4 \\
\hline High $^{* * *}$ & 88.0 & 79.8 \\
\hline Extreme $^{* * * *}$ & 6.0 & 1.6 \\
\hline
\end{tabular}

$$
\text { * } 0-2.5 \% ; * * 2.5-12 \% ; * * * 12-50 \% ; * * * *>50 \% \text {. }
$$

Table 2 - Percentage of vertical curvatures of hillslopes existing in the investigated watersheds

\begin{tabular}{c|c|c}
\hline Vertical Curvature & Ribeirão Mata Porcos & Rio do Peixe \\
\hline Convex* $^{*}$ & 37.5 & 32.2 \\
\hline Straight** $^{*}$ & 16.2 & 27.7 \\
\hline Concave*** $^{*}$ & 46.3 & 40.1 \\
\hline
\end{tabular}

*Values higher than $0.010^{\circ} / \mathrm{m}$; **values between $0.010 \% \mathrm{~m}$ e $-0.010 \% \mathrm{~m}$; values lower than $-0.010 \% \mathrm{~m}$.

Analysis of topographic profiles reveal a general decrease in the heights of the summits to the east, with a more marked decrease near the water gaps (Figures 4 and 5).

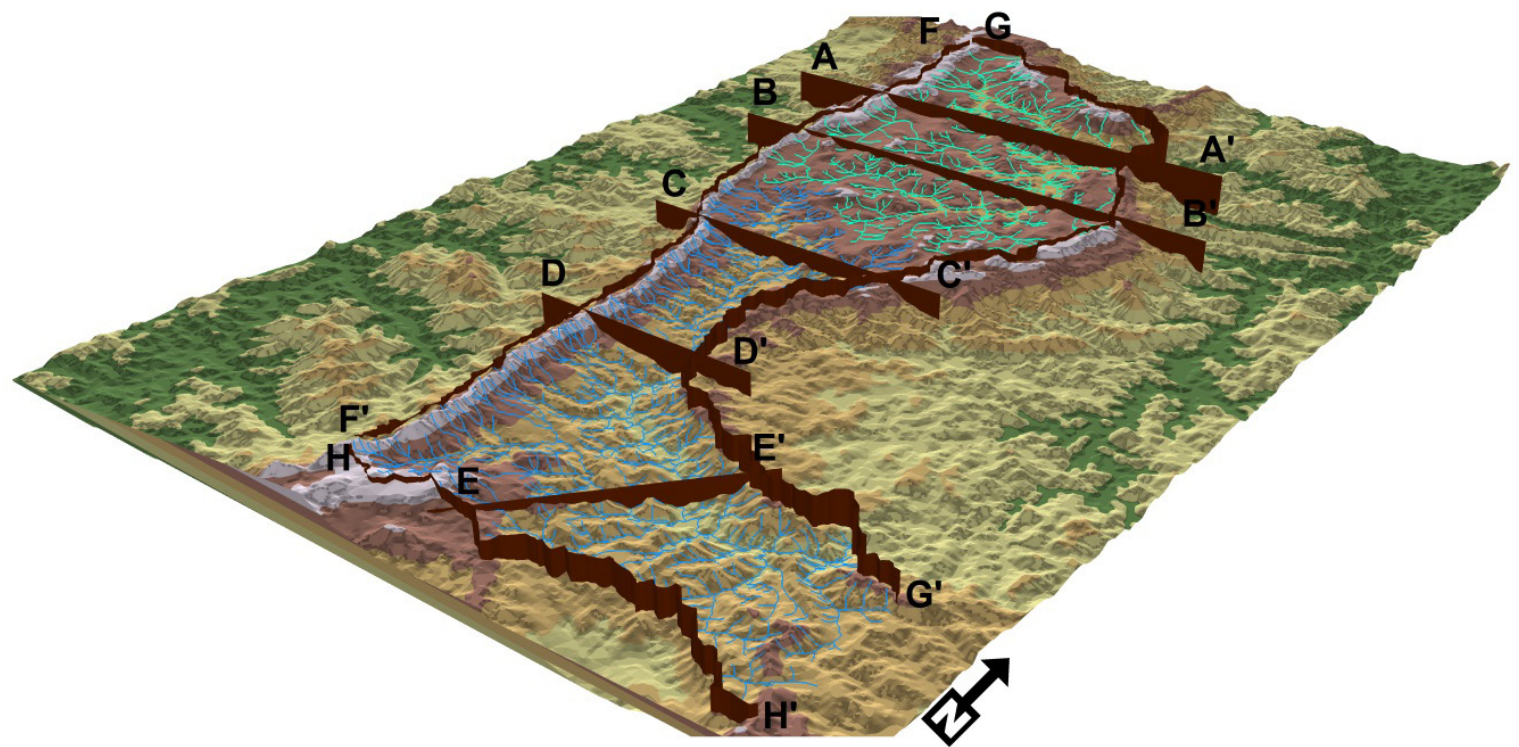

Figure 4 - Location of the topographic profiles designed along the Moeda syncline. The profile names are in alphabetical order with respect to their location (from $\mathrm{N}$ to $\mathrm{S}$ ). 


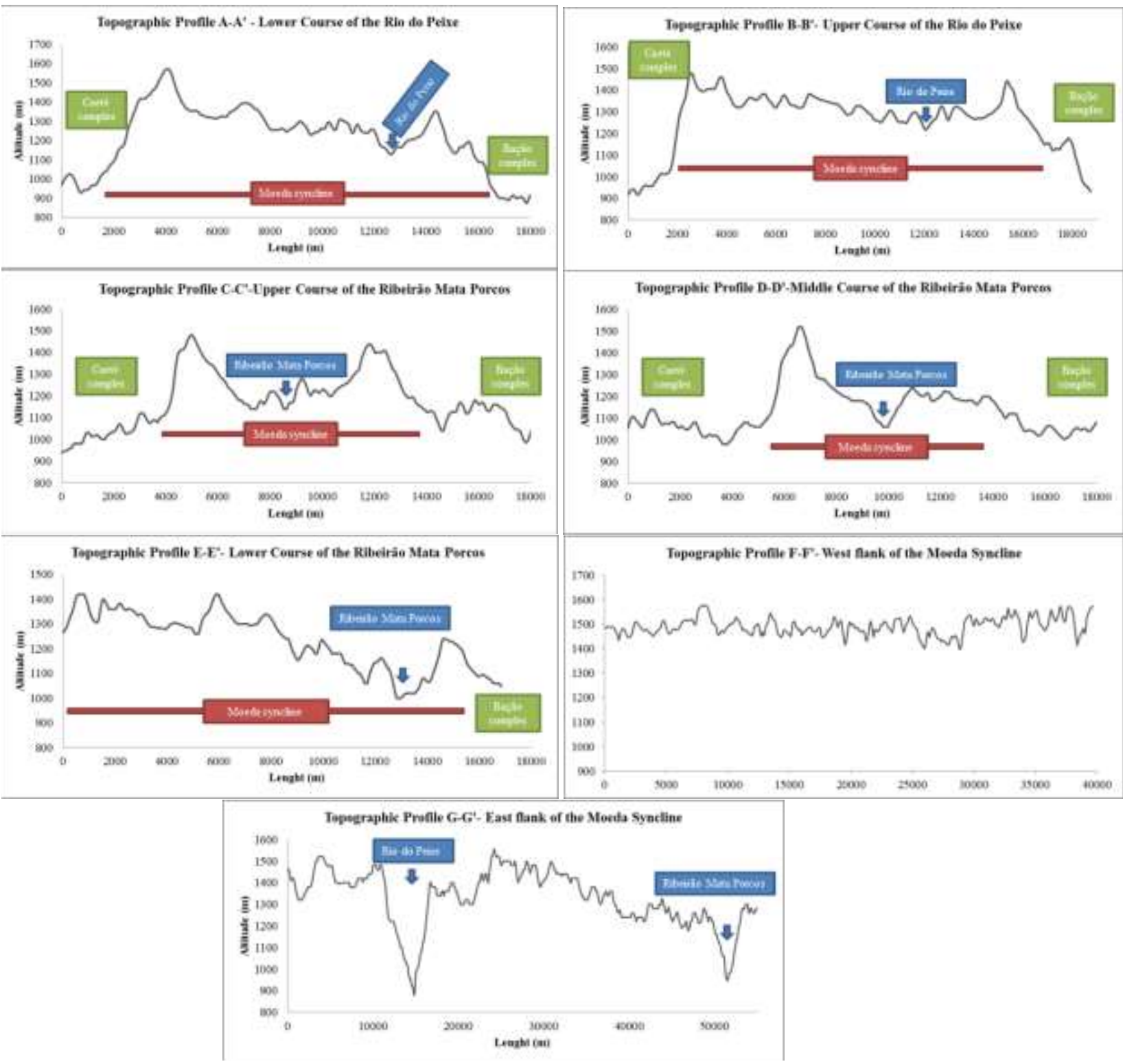

Figure 5 - Topographic profiles created from DEMs provided by the Instituto Nacional de Pesquisas Espaciais (Inpe). The ordinate shows elevation (m), and the abscissa shows the horizontal scale (m).

The syncline's east flank exhibits a smoother elevation change than does the lower portions of the Bação Complex. The syncline's west flank (bordered by the Caeté Complex) is characterized by an escarpment.

Along the Moeda syncline's edges, the elevation is stable, with an upward trend on the west flank from north to south. In the eastern portion, there is a considerable drop to the south, i.e., the opposite of the pattern observed on the west side. 
The Rio das Velhas, which constitutes the base level of the Moeda syncline's drainage area, is situated above the Rio Paraopeba in the western area. The Ribeirão Mata Porcos outflows the syncline in a higher elevation than the Rio do Peixe and, thus, is controlled by a higher base level.

\section{Drainage density and drainage inflections}

The two analyzed drainage basins underlain by the Moeda syncline exhibit two very distinct drainage densities. Although both basins are underlain by similar rocks, the Ribeirão Mata Porcos watershed exhibits much higher drainage density values than does the Rio do Peixe watershed (Figure 6).
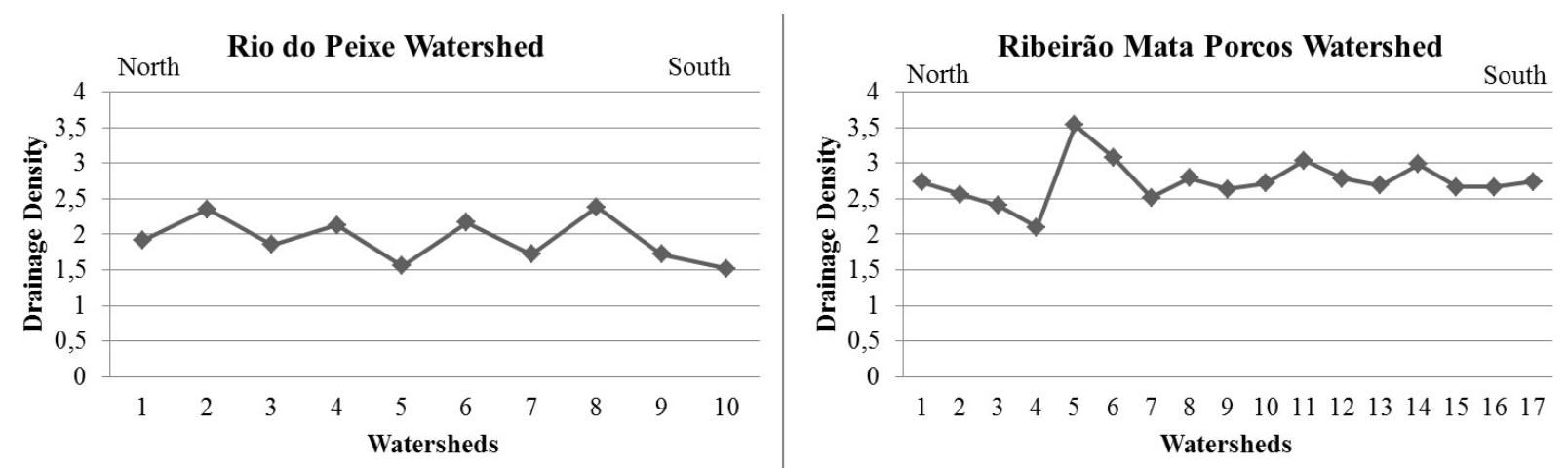

Figure 6 - Drainage density values in the two researched watersheds from N (left) to S (right). In general, the results the drainage densities in the Ribeirão Mata Porcos watershed are higher than those in the Rio do Peixe.

The Rio do Peixe watershed exhibits the lowest drainage density of all of the watersheds located in the Quadrilátero Ferrífero. Moreover, the probability that these two watersheds have different drainage densities is approximately $99.99 \%$ (Table 3 ).

Table 3 - Analysis of variance of the drainage density values in the researched watersheds. The extremely low p-value demonstrates a probability higher than 99.99 \% of the Rio do Peixe and Ribeirão Mata Porcos watersheds have distinct drainage densities

\begin{tabular}{c|c|c|c|c|c|c}
\hline Source of variation & $\boldsymbol{S S}$ & $\boldsymbol{d} \boldsymbol{f}$ & $\boldsymbol{M S}$ & $\boldsymbol{F}$ & $\boldsymbol{p}$-value & Critical $\boldsymbol{F}$ \\
\hline Between groups & 2.12 & 1 & 2.12 & 24.36 & 0.000149 & 4.49 \\
\hline Within groups & 1.39 & 16 & 0.087 & & & \\
\hline & & & & & & \\
\hline Total & 3.52 & 17 & & & & \\
\hline
\end{tabular}

The existing inflections (elbows) in the river network do not show randomness (Figure 7). In the Rio do Peixe watershed, the more distinct inflections are those with N-S orientations near the syncline's west edge. The exception is the main valley, where there are two inflections near the eastern flank, one in the upper course and the other near the water gap. 


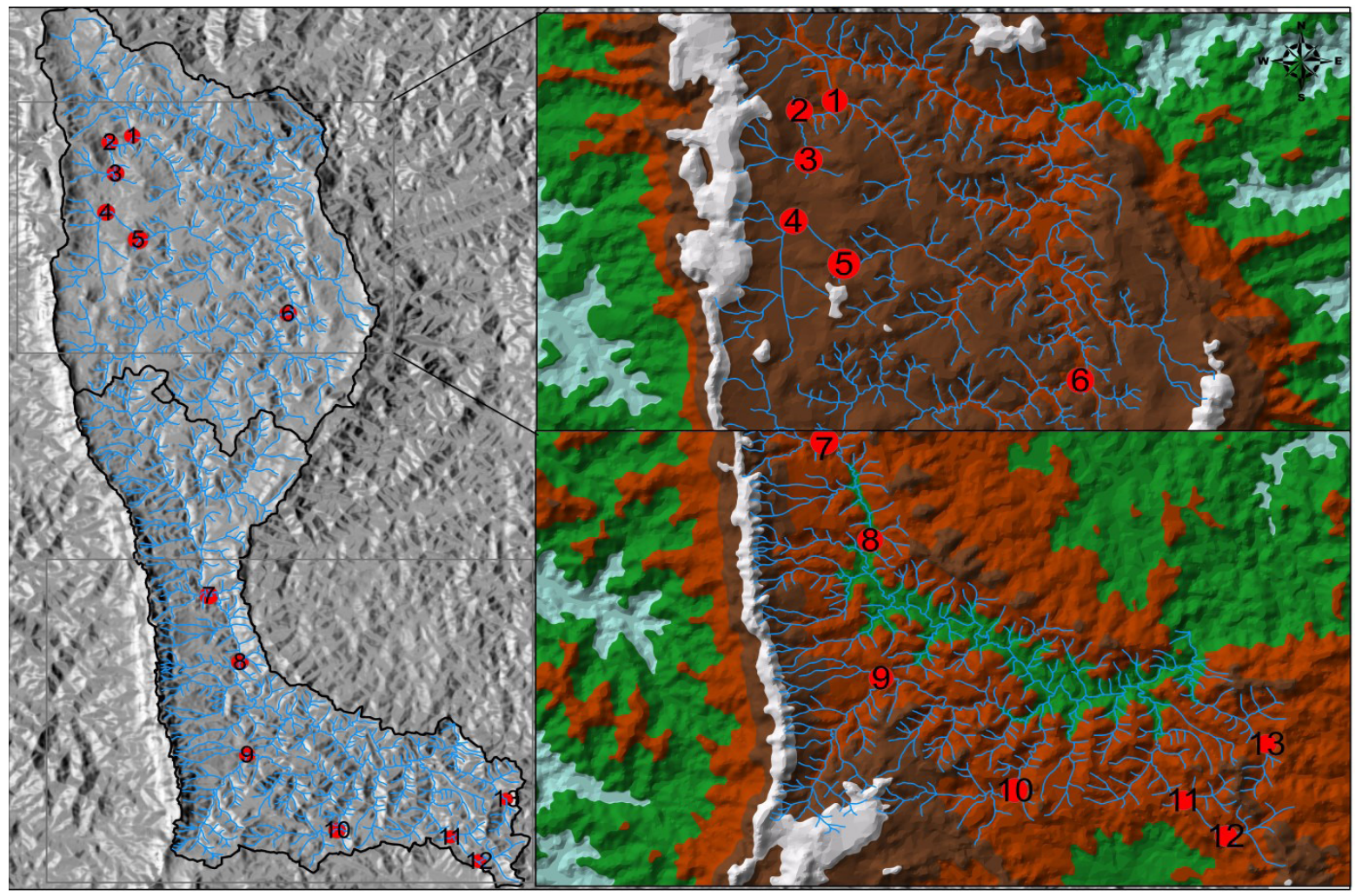

Figure 7 - Distribution of the main inflections (elbows) in the river network. There are two well-defined groups: (i) one in the Rio do Peixe, near the west edge; and (ii) another in the Ribeirão Mata Porcos, close to the southern drainage divide.

In the Ribeirão Mata Porcos watershed, the inflections exhibit two clear distribution patterns. One is located in the middle course, near the dextral strike-slip faults, where there are two well-defined inflections. Another set of inflections is located in the lower course, specifically on the right margin's main tributaries and near the south syncline's drainage divide.

The river network's orientation upstream of certain of these inflections is similar to the orientation of certain nearby rivers (Figure 8).

In the left margin's tributaries of the Rio do Peixe, there are channels with orientations (N-S) very similar to those of the segments located upstream of the inflections. In contrast, the orientations of the rivers upstream of the elbows of the lower course of the Ribeirão Mata Porcos are similar to those located in the marginal watersheds that drain into the Rio Paraopeba (Table 4). 

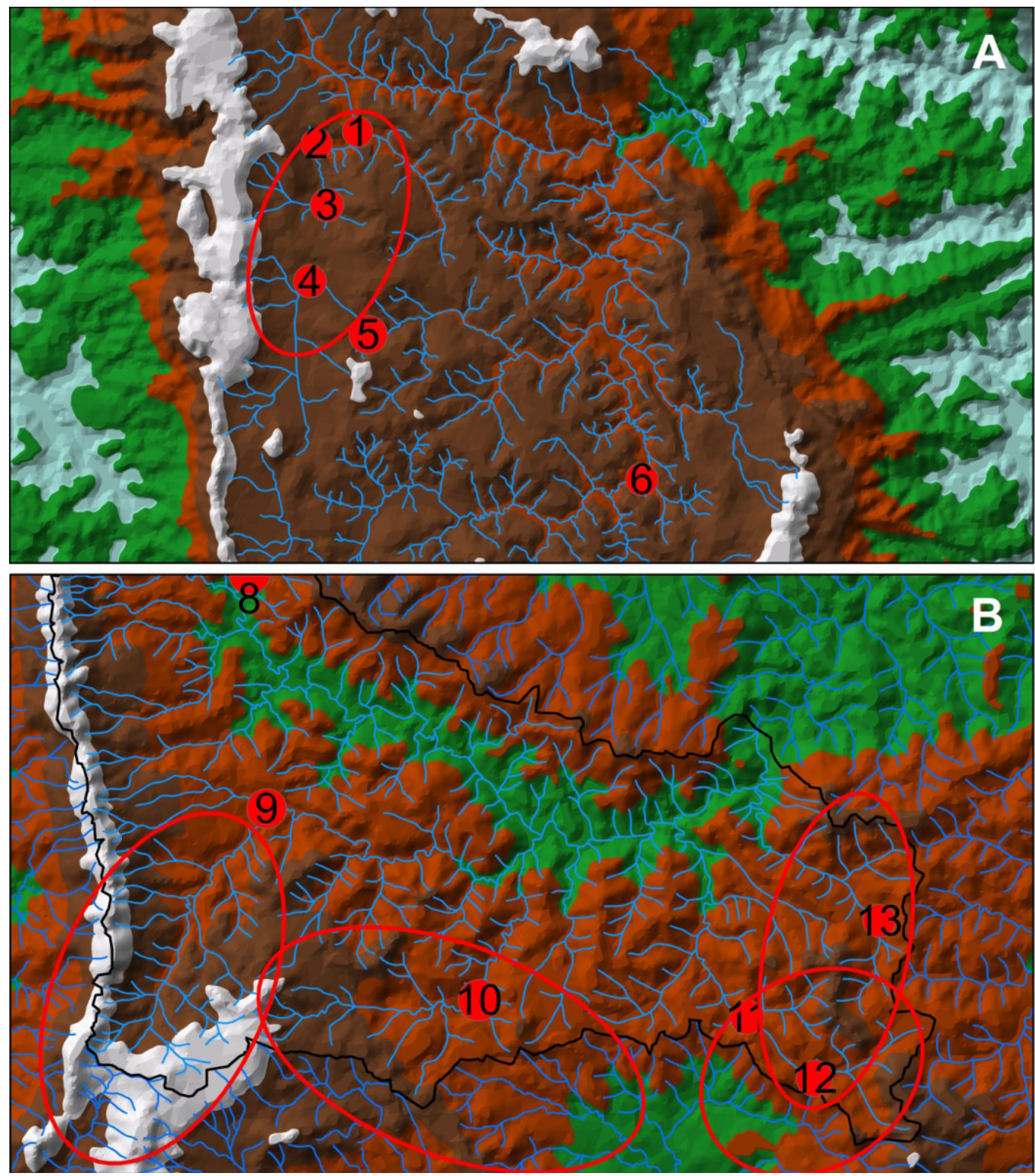

Figure 8 - Neighboring drainage network with orientations similar to those of the segments located upstream of the elbows (in red circles).

Table 4 - Drainage network orientation of the most significant inflection points (elbows). The orientation upstream of the inflections is more similar to some neighboring drainage networks than those downstream of the elbows, especially in the lower course of the Ribeirão Mata Porcos

\begin{tabular}{c|c|c|c}
\hline Points & $\begin{array}{c}\text { Orientation upstream of the } \\
\text { elbow }\end{array}$ & $\begin{array}{c}\text { Orientation of the neighboring drain- } \\
\text { age network }\end{array}$ & $\begin{array}{c}\text { Orientation downstream of } \\
\text { the elbows }\end{array}$ \\
\hline 3 & S012E-N012W & N008W-S008E & N010W-S010E \\
\hline 9 & N060E-S060W & N040E-S040W & S020E-N020W \\
\hline 10 & N036W-S036E & N041W-S041E & N034E-S034W \\
\hline 11 & N061E-S061W & N050E-S050W & N018W-S018E \\
\hline 12 & N078E-S078W & N006W-S006E & N050W-S050E \\
\hline
\end{tabular}

\section{STREAM LENGTH-GRADIENT}

The results obtained through the stream length-gradient indexes indicate the preferred locations of river segments with no anomalies and those with first-and second-order anomalies (Figure 9). 


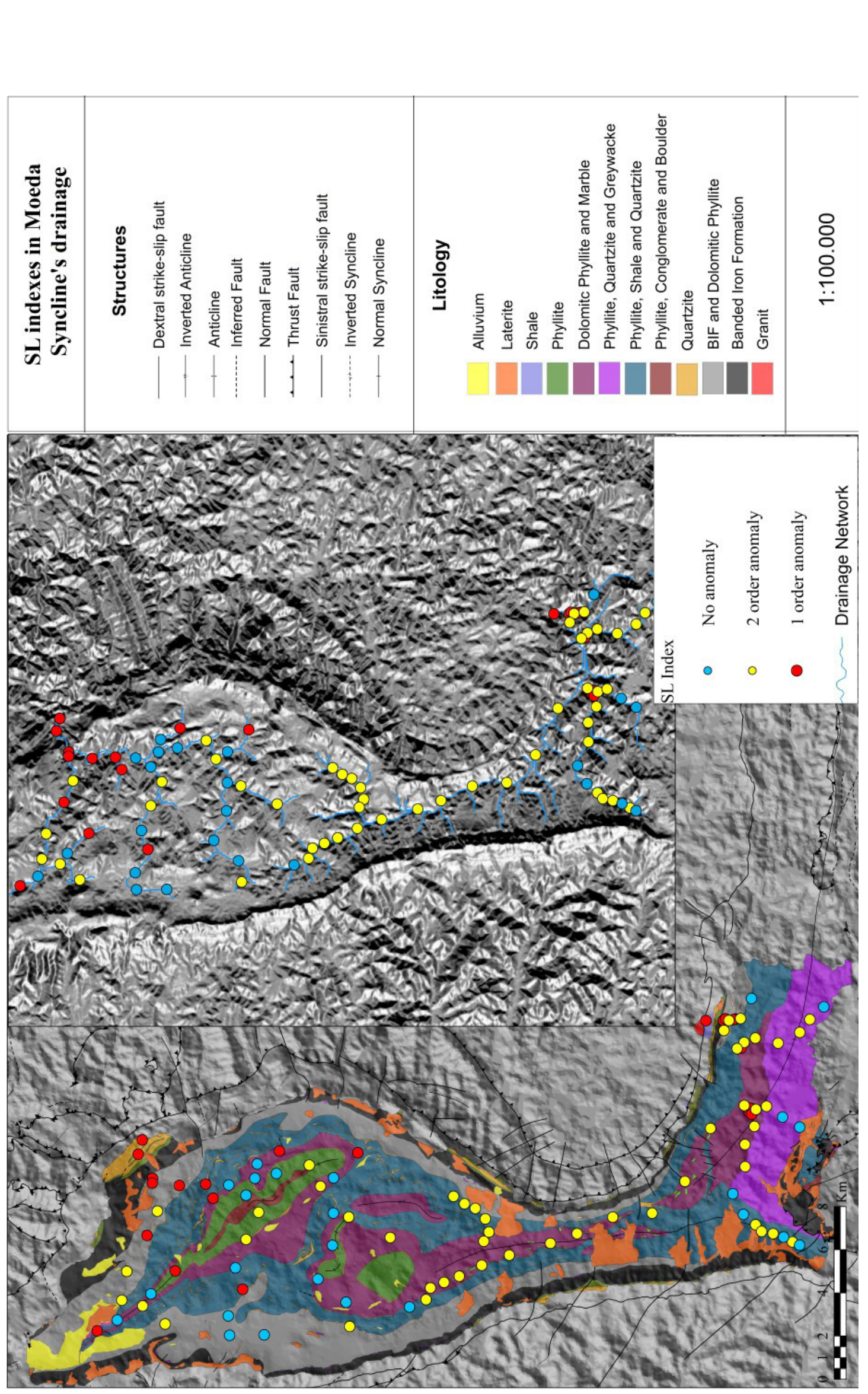


In the Rio do Peixe watershed, there is a concentration of 1st-order anomalies next to the water gap and in scattered confluences along both margins. In the Ribeirão Mata Porcos watershed, the anomalies are more concentrated near the water gap and at the confluences of the two main sub-basins in the lower course. In general, 1st-order anomalies of the Ribeirão Mata Porcos are all located in the lower course between its main valley's edges and its right margin main tributaries.

Furthermore, the range of anomalies differs substantially between the investigated drainage basins (Table 5).

Table 5 - Percentage of the range of anomalies in the analyzed drainage basins. According to the table, the most significant change occurred between the "no anomaly" and "2nd order anomaly" categories

\begin{tabular}{c|c|c|c}
\hline Drainage basin & No anomaly $(\%)$ & $2^{\text {nd }}$-order anomaly $(\%)$ & $1^{\text {st }}$-order anomaly $(\%)$ \\
\hline Mata Porcos & 14.3 & 60.7 & 25.0 \\
\hline Rio do Peixe & 36.6 & 31.7 & 31.7 \\
\hline
\end{tabular}

\section{ASYMMETRY FACTOR AND TRANSVERSE TOPOGRAPHIC SYMMETRY FACTOR}

The asymmetry factor revealed that $64 \%$ of the Rio do Peixe watershed and $70.6 \%$ of the Ribeirão Mata Porcos watershed are drained by only one of their margins.

The transverse topographic symmetry factor indicates a statistically significant preferred migration of the Rio do Peixe, whereas its sub-basin tributaries display insignificant values (lower than 0.05 , Table 6).

Table 6 - Mean values (T) extracted from the main tributaries of the Rio do Peixe. The Rio do Peixe has the highest mean vector (T) and the lowest significance level (p) than its tributaries

\begin{tabular}{c|c|c|c}
\hline Watershed's segment & Mean Vector (T) & Mean Direction (in degrees) & Sign. $(\boldsymbol{p})$ \\
\hline Rio do Peixe & 0.39 & 113.04 & 0.012 \\
\hline Tributary of the medium course & 0.36 & 153.80 & 0.057 \\
\hline Tributary of the lower course & 0.28 & 102.23 & 0.075 \\
\hline
\end{tabular}

In contrast, the corresponding values of the Ribeirão Mata Porcos indicate an increase in the statistical significance of the preferred migration as this river approaches the water gap, particularly the middle-lower course where it inflects to the southeast (Table 7). The upstream segments down to the middle course of the Ribeirão Mata Porcos, with significance levels lower than 95\% (0.05), are not considered preferred migrations.

Table 7 - Mean values extracted from many segments of the Ribeirão Mata Porcos. In general, the mean direction presents significant variations and the increase of the mean vectors $(\mathrm{T})$ is similar to the values found in the statistical significance values $(\mathrm{p})$

\begin{tabular}{c|c|c|c}
\hline Watershed's segment & Mean Vector (T) & Mean Direction (in degrees) & 91.05 \\
\hline Upper course & 0.088 & 244.33 & 0.956 \\
\hline Upper-medium course & 0.271 & 78.04 & 0.559 \\
\hline Medium course & 0.364 & 172.60 & 0.163 \\
\hline Medium-lower course & 0.528 & 214.05 & 0.002 \\
\hline Lower course & 0.301 & 160.54 & 0.033 \\
\hline
\end{tabular}

Similarly, the channel migration vectors display directions that vary considerably within the same watershed and differ from those of nearby watersheds (Figure 10). 


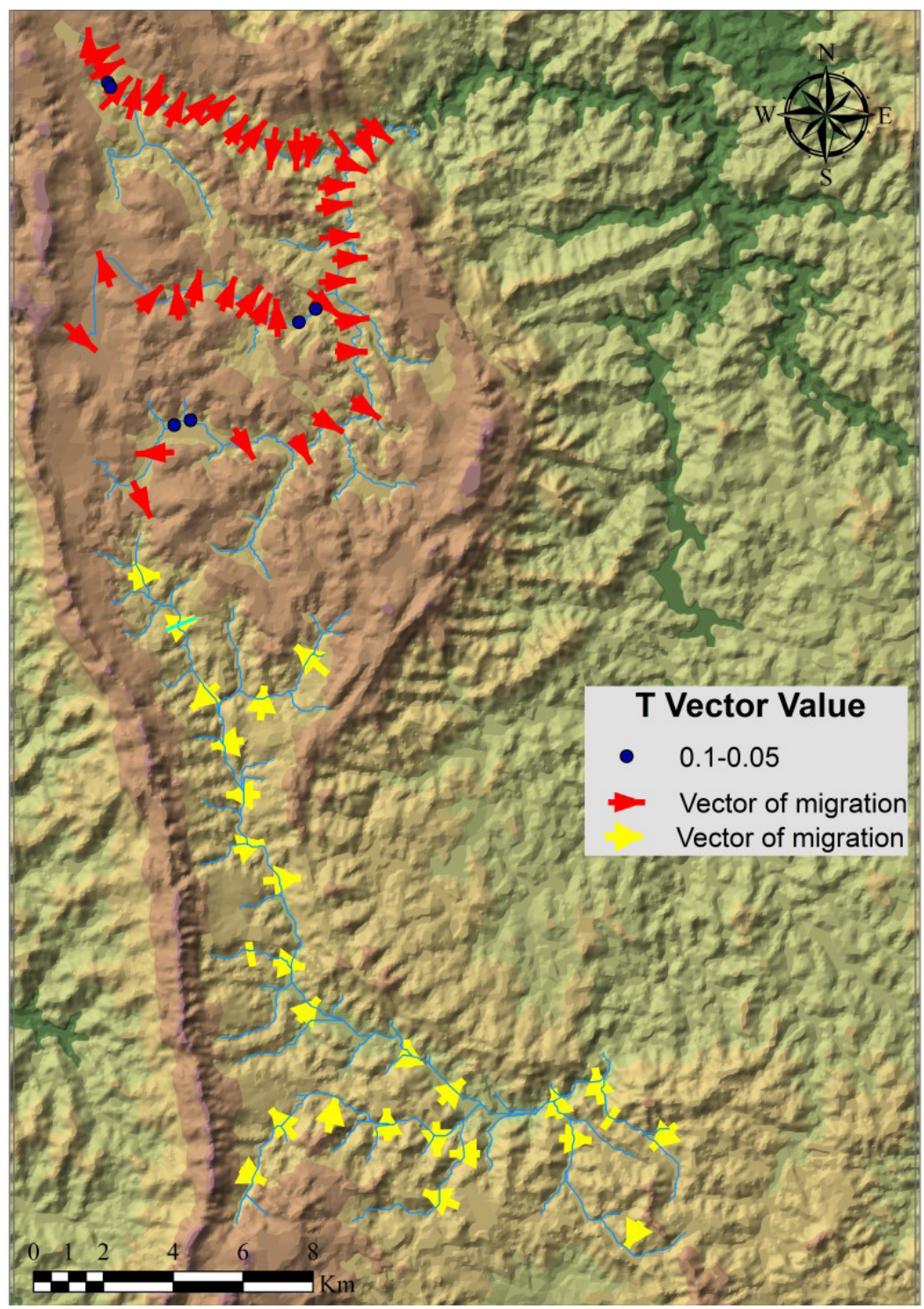

Figure 10 - Mean vectors obtained from the values of transverse topographic symmetry (T). The blue points denote segments without significant migration. The red vectors belong to the Rio do Peixe watershed, and the yellow vectors belong to the Ribeirão Mata Porcos watershed.

\section{RELIEF RATIO}

There is also a pattern in the relief ratios of specific segments of the watersheds. The relief ratios of the Rio do Peixe watershed are markedly lower than those of the Ribeirão Mata Porcos watershed (Figure 11).

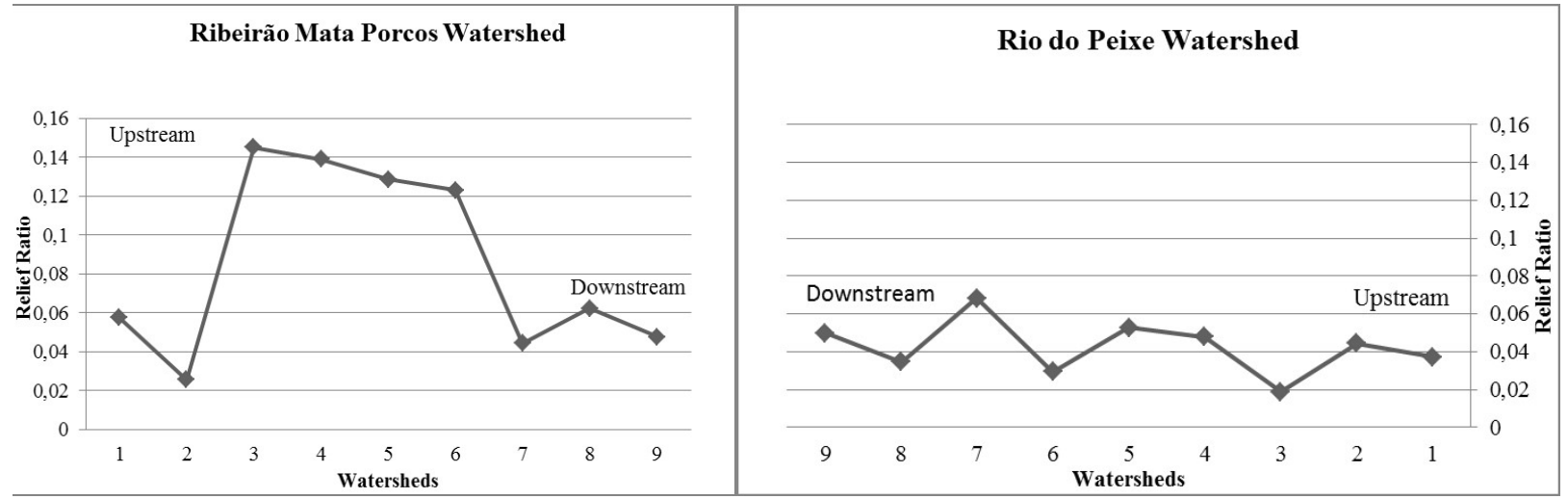

Figure 11 - Relief ratios (ordinates) and watershed locations (abscissas). 
In general, the Rio do Peixe yielded values with higher randomness, ranging between 0.02 and 0.07. At the same time, the data from the Ribeirão Mata Porcos exhibited two distinct patterns: one set of values was located in the upper and lower courses and ranged between 0.06 and 0.02 , and the other set, located in the medium course, yielded values between 0.15 and 0.12 .

Statistically, the significance level indicated that the probability of these watersheds having equal values is less than $2 \%$ (Table 8 ).

Table 8 - Analysis of variance of relief ratio between the Ribeirão Mata Porcos and Rio do Peixe watersheds. The p-value indicated low probability (in decimal scale) of equal relief ratio values for the watersheds

\begin{tabular}{c|c|c|c|c|c|c}
\hline Source of variation & $\boldsymbol{S S}$ & $\boldsymbol{d f}$ & $\boldsymbol{M S}$ & $\boldsymbol{F}$ & $\boldsymbol{p}$-value & Critical $\boldsymbol{F}$ \\
\hline Entre grupos & 0.008541 & 1 & 0.008541 & 6.491868 & 0.023211 & 4.60011 \\
\hline Dentro dos grupos & 0.01842 & 14 & 0.001316 & & & \\
\hline & & & & & & \\
\hline Total & 0.026961 & 15 & & & & \\
\hline
\end{tabular}

\section{HYPSOMETRIC INTEGRALS AND CURVES}

The hypsometric integrals of the most distinct sub-basins of the Moeda syncline range between 0.30 and 0.54 . The spatial distribution of these values displays a sharp distinction between the two main drainage basins underlain by the syncline (Fig. 12).

In the Rio do Peixe basin, the majority of the tributary basins have HI values ranging between 0.30 and 0.45 , with only two sub-basins next to the outlet yielding higher values. In contrast, in the Ribeirão Mata Porcos basin, eight of thirteen investigated sub-basins are in the group with the highest HI values. These sub-basins are generally distributed across the entire basin, decreasing only in the middle course.

The hypsometric curves also exhibit distinct characteristics. The majority of the Rio do Peixe watershed displays a low height variation, with a sharp relief increase in only a relatively small area. In general, the hypsometric curves of the Rio do Peixe's tributaries are below that of the Rio do Peixe valley in the upper course, closer to it in the medium course and reach the maximum distance in the lower course.

The Ribeirão Mata Porcos watershed yielded a smoother downward curve than did the Rio do Peixe. The tributary curves of the Ribeirão Mata Porcos are mostly higher than the Rio do Peixe in the upper course, below it in the middle course and closer to it in the lower course.

\section{DENUDATION AND DOWNWEARING RATE OF THE MOEDA SYNCLINE}

The Ribeirão Mata Porcos and Rio do Peixe watersheds have similar values of the mean eroded volume, i.e., $19.83 \mathrm{~km} 3$ and $19.15 \mathrm{~km} 3$, respectively. However, the mean landform downwearing in these two basins differs greatly. The area drained by the Ribeirão Mata Porcos displays a mean downwearing of $121.46 \mathrm{~m}$, while the corresponding value of the area drained by the Rio do Peixe is $108.06 \mathrm{~m}$.

This difference becomes clearer when the downwearing values within these basins are analyzed (Figure 13).

In the Rio do Peixe watershed, the more distinct values are concentrated in the lower course, whereas the inverse is true in the Ribeirão Mata Porcos watershed: the highest values are in the upper and middle courses, and the lowest values are concentrated in the lower course. 

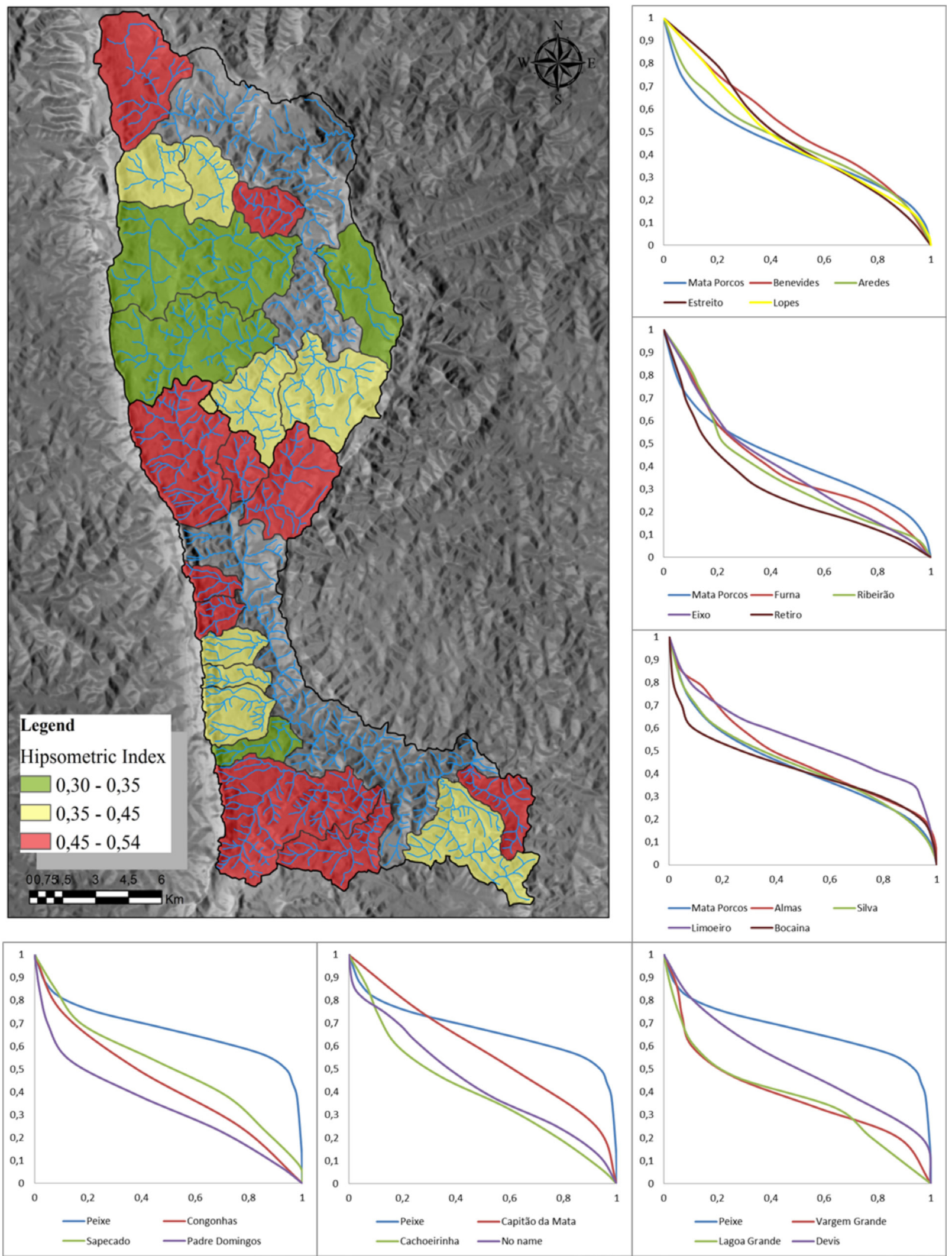

Figure 12 - Hypsometric index throughout the Moeda Syncline (on the map). Hypsometric curves of the Ribeirão Mata Porcos (on the right side) from upstream (top) to downstream (bottom). The hypsometric curves of the Rio do Peixe are displayed on 


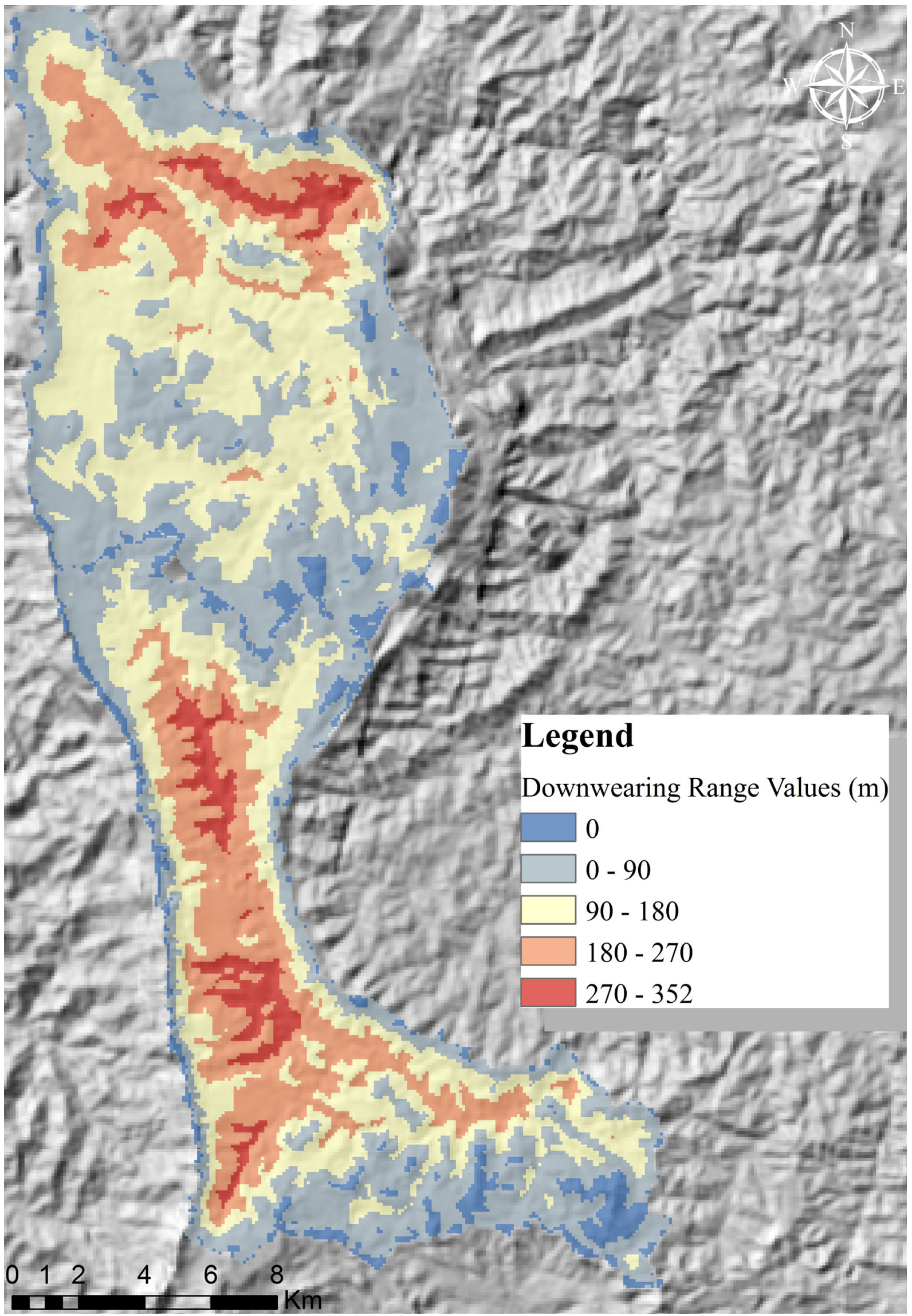

Figure 13 - Downwearing values in the Moeda syncline. Note the concentrated pattern and nonrandom values approaching zero and higher than $270 \mathrm{~m}$. 


\section{DISCUSSION}

\section{THE OPENING OF THE MOEDA SYNCLINE AND ITS WATER GAPS}

Two of the fundamental requirements for the occurrence of river capture are the presence of sufficiently low relief between the involved channels and the need for the capturing river to be lower than the captured river (HOWARD, 1971; SMALL, 1978; BISHOP, 1995). Based on these assumptions, the locations and the limited number of water gaps on the western flank of the Moeda syncline, understood as evidence of river capture related to the relief inversion in the Quadrilátero Ferrífero (BARBOSA, 1949; KING, 1956; DORR, 1969), appear to be confirmed by the topographic profiles (Fig. 5).

In the west, the Rio Paropeba represents a lower base level, but only in the eastern flank drained by the Rio das Velhas are the two conditions required for river capture present. On a large scale, the presence of these conditions can be associated with the higher uplift rates of the Quadrilátero Ferrífero and its interior (SAADI, 1991; MAGALHÃES JÚNIOR, 1993). This uplift would have allowed an expansion of the drainages of the Rio das Velhas tributaries and an increase in relief along the western ridge top and, thus, hindered any capture on this side of the syncline. On a medium scale, it is important to consider the abundant evidence of crustal uplift along the Rio das Velhas Valley (MAGALHÃES JÚNIOR, 1993; SANTOS, 2010) and its tributaries (MAGALHÃES JÚNIOR et al., 2010; BARROS, 2012). In addition to the neotectonic features, the lower resistance to erosion of the Bação Complex's granites (SALGADO, 2008; VARAJÃO et al., 2009) may also explain the occurrence of river capture on the western edge, primarily in the Ribeirão Mata Porcos.

Thus, crustal uplifts and lithological resistance, which provide sufficient gradient, energy and erosive power for the expansion of the capturing river, may be considered key factors in the occurrence of captures, such as those in the Moeda syncline (CLARKE, 1989; CALVACHE; VISERAS, 1997; WENZENS; WENZENS, 1997).

\section{WAVE OF INCISION AND DENUDATION IN THE MOEDA SYNCLINE}

After a river capture, one of the most common phenomena is the upward waves of incision (MATHER 2000; STOKES et al., 2002; LOGET; DRIESSCHE, 2009), which is common even in paleoendoreic watersheds (CALVACHE; VISERAS, 1997; ANTÓN et al., 2013), which the Miocene watersheds of the Moeda syncline were (BARBOSA, 1949; BARBOSA; RODRIGUES, 1965). Based on the drainage density (Fig. 6), stream length-gradient index (Fig. 9), relief ratio (Fig. 11) and hypsometric integrals and curves (Fig. 12), it is possible to identify headward waves of incision events in certain areas underlain by the syncline.

Due to the great lithostratigraphic variability of the Moeda syncline, it is possible that a number of the 1st-order anomalies, which are generally related to knickpoints (MOLIN et al., 2004), were generated by lithologic variations (Fig. 9). Although there are numerous knickpoints near the water gaps, which could be related to an upward migration of dissection from the new base level, the numerous knickpoints in the lower course of the Ribeirão Mata Porcos tributaries can be understood in terms of the existing morphologic and lithologic variations. Among all of the anomalies, only one is located on a tectonic lineament, indicating that there are explanations other than tectonic-structural ones for the majority of the anomalies.

However, these anomalies are distributed differently in the two investigated watersheds. The 1st-order anomalies are located at isolated points in the lower course of the Ribeirão Mata Porcos, whereas the Rio do Peixe anomalies are more scattered, primarily in the lower and middle courses. Therefore, there are areas with distinct concentrations of knickpoints, frequently referred to as knickzones (SCHLUNEGGER; SCHNEIDER, 2005; HAYAKAWA; OGUCHI, 2006; FOSTER; KESLEY, 2012), only in the Rio do Peixe. 
The distribution of these anomalies in the drainage basins reveals important features. In general, the presence of knickzones is evidence of transient geomorphological states, which demonstrate the response of the fluvial system in search of an equilibrium with respect to the new base level (ZAPROWSKI, 2001; AGUILLAR et al., 2011; LARUE, 2011). If tectonic-structural explanations are discarded as causes of the anomalies, the knickzones can be understood as key features of the headward propagation of a wave of incision caused by captures (BEGIN et al., 1982; ANTÓN et al, 2013).

In the Rio do Peixe watershed, keeping in mind the unlikely litho-structural and regional explanations for the knickpoints (Fig. 9), it may be inferred that the knickpoints represent a knickzone that propagates upward in the lower course tributaries, possibly related to the recent capture of these river channels.

In the case of the Ribeirão Mata Porcos watershed, the association of a more resistant lithological unit, the low downwearing measured from the paleosurface $(0-90 \mathrm{~m})$, the relatively high value of the hypsometric integral (0.35-0.45) and the hypsometric curves' shapes, which indicates a slightly younger landform (Fig. 12), supports the lithological influence hypothesis for the right margin tributaries of the lower course of the Ribeirão Mata Porcos.

The morphological effects caused by the wave of incisions are distinct along the Moeda syncline. Because the anomalies and the erosive power are situated near the Rio do Peixe's outlet, its upper and middle courses exhibit low downwearing values (0-180 m) and low to medium hypsometric integral values (0.35-0.45). Those characteristics are the opposite of the high values found in the lower course, where there is high downwearing $(180-552 \mathrm{~m})$ and hypsometric integral values. Thus, the correspondence between the knickzone areas and the morphological pattern described above is evidence of various evolutionary stages and of upward propagation of a wave of incision in the Moeda syncline.

A higher stage of evolution and denudational in the Ribeirão Mata Porcos was noted, based on the restriction of knickpoints to the areas of lithologic change, suggesting that there is no direct connection between the watershed's landform evolution and the current knickzone location. In contrast, the Rio do Peixe, whose large number of knickpoints and marked contrast between the propagation area of the wave of incision and the low relief upstream, seems to be undergoing geomorphologic evolution directly associated with the river network's current expansion and its wave of incision. Thus, it is plausible that the Rio do Peixe is in an earlier stage of evolution and is chronologically younger than the Ribeirão Mata Porcos.

This evidence, together with the distinct timing of captures of the watersheds, demonstrates that the morphological disequilibrium currently observed in the Ribeirão Mata Porcos may also occur in the Rio do Peixe watershed, based on the wave of incision's advance. This capture would be the result of the energetic and transient morphological condition of the Rio do Peixe watershed, which exhibits evidence of waves of incision and knickzones similar to those observed in other areas (PRINCE et al., 2011; PEDERSON; TRESSLER, 2012).

Aside from the captures at various times, the beheading processes may also explain the distinct evolution and denudational patterns of the landform, as has been observed in other cases (BISHOP, 1995; WHITEMAN; ROSE, 1997; MAHER et al., 2007). The beheading process may have been active due to the higher energy and relief in the Ribeirão Mata Porcos than in the Rio do Peixe, and the lower elevation of the Ribeirão Mata Porcos may have allowed its expansion and the capture of the Rio do Peixe's drainage area without maintaining the ancient river channel morphology.

Based on the lower elevation of the Ribeirão Mata Porcos and its older capture, it is possible that, in addition to the capture of the Rio do Peixe drainage area, piracy of groundwater flow may have occurred, as often happens in such circumstances (KAFRI; YECHIELI, 2010). The capture of its groundwater may have caused an increase in the denudational power of the Ribeirão Mata Porcos and a decrease in the surface water in the Rio do Peixe watershed, generating extremely 
low drainage density values (Fig. 6). Thus, there was maintenance of the pseudo-karstic landforms (BARBOSA; RODRIGUES, 1965) and the extremely asymmetric drainage pattern (Tables 6 and 7).

\section{PROBABLE CAUSES OF THE RIVER NETWORK'S PREFERRED MIGRATION}

The preferred migration of river channels that is not random or generated by internal hydrodynamics has been explained primarily by tectonic tilting (COX, 1994; SALVANY, 2004; ÖZKAYMAK; SÖZBILIR, 2012). However, river captures themselves may generate directional changes of river channels (SMALL, 1978; BISHOP, 1995), mostly in watersheds that developed from water gaps (CHORLEY et al., 1984; SUMMERFIELD, 1991).

In the case of the Moeda syncline's drainage basins, both situations may be coherent. The transverse topographic symmetry factor $(\mathrm{T})$ indicates the presence of the main river channels' preferred migration in the two analyzed watersheds (Tables 6 and 7; Fig. 10). This migration is statistically significant, particularly in the water gap, and allows an evaluation of whether the migration's likely origin was tectonics, with tilting to the east, the river capture itself, or a combination of tilting and capture.

The widespread tilting in the Rio das Velhas valley to the east (LANA, 2010), thrusting of the Bação Complex over the Moeda syncline's supracrustal rocks (LIPSKI, 2002; SANTOS, 2003), possible tectonic inversions (GOMES et al., 2005; CHEMALE JR. et al., 1991) and the drainage rearrangement generated by captures are strong evidence of the combined action of these mechanisms. Due to the multiplicity of factors that contributed to the preferred migration and the difficulty of distinguishing between causal factor and fluvial responses, both the syncline's tilting to the east and the watershed captures are plausible explanations for the Quaternary basin evolution.

In the case of the Rio do Peixe, beyond the likely influence of tilting, it is worth considering that the anomalous drainage may be directly related to the endoreic and pseudo-karstic environment during the Miocene. The effects of this setting may have carried forward into the Holocene through the preservation of the extremely anomalous drainage patterns (BARBOSA, 1949; BARBOSA; RODRIGUES, 1965).

\section{ELBOWS AND DIRECTION CHANGES OF THE FLUVIAL CHANNELS}

The directional changes and fluvial channel elbows in the two main drainage basins underlain by the Moeda syncline exhibit distinct patterns and most likely have distinct causes.

The elbows observed in the Ribeirão Mata Porcos watershed are concentrated nearly exclusively in the lower course, upstream of the watersheds with 1st-order anomalies (Fig. 8). One factor that differentiates these inflections is the coincident direction of certain segments upstream of the elbows and the orientations of neighboring channels in other watersheds (elbows 9, 10, 11, 12 and 13). As structural influences were not verified, the inflections may have been caused by diversion or river captures sensu strictu, given that the possible capturing streams are lower than the captured ones, as observed by Small (1978) and Bishop (1995). The hypothesis of river captures sensu strictu is consistent with the greater dissection by and energy of capturing streams, primarily in the absence of structural lineaments required for tilting near the drainage divides.

In the Rio do Peixe watershed, the drainages upstream of the elbows exhibit orientations similar to those of other channels within a given watershed, indicating a possible internal reorganization of the river network. The main inflections (elbows 2, 3, 4 and 5) trend east, whereas the possible capturing streams (downstream of the elbows) are in states of much higher dissection than are the upstream drainages.

The genesis of these inflections may have a tectonic origin, i.e., tilting to the east or may be due to river captures sensu strictu. As discussed earlier, the most likely cause is a combination of these two factors during the Quaternary, either with different patterns of timing and dynamics or simultaneously, as these processes have been occurring in the large structural blocks and in the 
geomorphological evolution of the Quadrilátero Ferrifero since the Neoproterozoic (BARBOSA, 1949; KING, 1956; BARBOSA; RODRIGUES, 1965; SAADI, 1991; ALKMIN; MARSHAK, 1998; MAGALHÃES JÚNIOR et al., 2012).

\section{FINAL CONSIDERATIONS}

Although there are certain interpretative difficulties in developing generalizations in all morphometric and morphological data analyses, primarily in a geologically complex area as the Moeda syncline, it was possible to develop some conclusions regarding the evolutionary history of the area.

In general, the two investigated watersheds were captured by the Rio das Velhas, and these events occurred at different times.

The Ribeirão Mata Porcos likely was captured first, allowing the advance of a wave of incision that denuded the watershed and lowered the base level. In the last capture phase, the drainage of certain channels that flowed to the Rio Paraopeba likely reversed, generating the elbows near the southern drainage divide. As these events occurred, the fluvial channels in the middle and lower courses likely migrated preferentially to the east, the groundwater in the upper course was pirated and portions of the Rio do Peixe watershed were beheaded.

The Rio do Peixe exhibits evidence of having been captured only later. The piracy of its waters and area by the Ribeirão Mata Porcos likely allowed the preservation of the upper course's morphology with only minor reworking caused by the downstream capture. The more distinct morphogenetic events occurred primarily in the lower course, where there is deep dissection of the hillslopes and, on a smaller scale, in certain fluvial channels where the elbows were generated.

In both cases, tectonic explanations for the channel migrations to the east complement the hypothesis of the capture by the Rio das Velhas.

Thus, the morphogenetic events responsible for the evolution of the basin underlain by the Moeda syncline during the Quaternary may be attributed primarily to river captures (sensu strictu, diversion and beheading), neotectonic causes and, locally, to lithologic and structural patterns.

\section{ACKNOWLEDGEMENTS}

We gratefully acknowledge the Coordenação de Aperfeiçoamento de Pessoal de Nível Superior (CAPES) for the MSc scholarship provided to two of the authors, the PRPq UFMG Pró-Reitoria de Pesquisa da Universidade Federal de Minas Gerais for financial support, and the 'Science without Borders' program and CAPES foundation for the PhD grant (BEX 13193-13-9) provided to one of the authors.

\section{BIBLIOGRAPHY REFERENCE}

AGUILLAR, G.; RIQUELME, R.; MARTINOD, J.; DARROZES, J.; MAIRE, E. Variability in erosion rates related to the state of landscape transience in the semi-arid Chilean Andes. Earth Surface Processes and Landforms 36, 13, 1736-1748, 2011.

ALKMIM, F.F.; MARSHAK, S. Transamazonian orogeny in the São Francisco craton, Minas Gerais, Brazil: evidence for Paleoproterozoic collision and collapse in the Quadrilátero Ferrífero. Precambrian Research 90, 29-58, 1998.

ANTÓN, L.; DE VICENTE, G.; MUÑOZ-MARTÍN, A.; STOKES, M. Using river long profiles and geomorphic indices to evaluate the geomorphological. Geomorphology xx, 1-12, 2013.

ATTAL, M.; TUCKER, G. E.; WHITTAKER, A. C.; COWIE, P. A.; ROBERTS, G. P. Modeling fluvial incision and transient landscape evolution: Influence of dynamic channel adjustment. J. Geophys. Res., 113, F03013, 2008. 
BABINSKI M.; CHEMALE JR., F.; SCHUMUS, W. R. The Pb/Pb age of the Minas Supergroup Carbonate Rocks, Quadrilátero Ferrífero, Brazil. Precambrian Research 72, 235-245, 1995.

BARBOSA, G.V.; RODRIGUES, D.M.S., O Quadrilátero Ferrífero e seus Problemas Geomorfológicos. Boletim Mineiro de Geografia 10, 11, p. 3-35, 1965.

BARROS, L. F. P. Eventos Sedimentares do Quaternário e Evolução Morfodinâmica do Vale do Rio Conceição - Quadrilátero Ferrífero/MG, 2012.

BEGIN, Z. B.; SCHUMM, S. A.; MEYER, D. F. Knickpoint Migration due to Baselevel Lowering. Journal of the Waterway Port Coastal and Ocean Division 106, 3, 369-388, 1982.

BISHOP, P. Drainage rearrangement by river capture, beheading and diversion. Prog. Phys. Geogr. 19, 449-473, 1995.

BOWMAN, I. A Typical Case of Stream-Capture in Michigan. The Journal of Geology 12, 4, 326-334, 1904.

CALVACHE, M. L.; VISERAS, C. Long-Term Control Mechanisms of Stream Piracy Processes in Southeast Spain. Earth Surface Processes and Landforms 22, 93-105, 1997.

CHEMALE JR. F.; ROSIÈRE, C. A.; ENDO, I. The Tectonic Evolution of the Quadrilátero Ferrífero, Minas Gerais, Brazil. Prec. Res. 65, 25-64, 1994.

CHORLEY, R.J.; SCHUMM, S.A.; SUGDEN, D.E. Geomorphology. Methuen, London, 1984.

CHRISTOFOLETTI, A. Análise de Sistemas em Geografia. Hucitec-Edusp, São Paulo, 1979.

CLARKE, G.M. Central and southern Appalachian water and wind gap origins: Review and new data. Geomorphology, 2, 209-232, 1989.

COX, R.T.. Analysis of drainage-basin symmetry as a rapid technique to identify areas of possible Quaternary tilt-block tectonics: an example from the Mississippi embayment. Geol. Soc. Am. Bull. 106, 571-581, 1994. CURRAY, J. R. The analysis of two-dimensional orientation data. Journal of Geology 64, 117-131, 1956.

DAVIS, W.M. The rivers and valleys of Pennsylvania. National Geographic Magazine 1, 183-253, 1890.

DAVIS, W.M. The development of certain English rivers. Geographical Journal 5, 127-46, 1895.

DORR II, J.V.N. Physiographic, Stratigraphic and Structural Development of the Quadrilátero Ferrífero, Minas Gerais, Brazil. Washington, U.S. Geological Survey (Professional Paper 641A), 1969.

ETCHEBEHERE, M. L. C.; SAAD, A. R.; CASADO, F. C. Análise Morfoestrutural Aplicada no Vale do Rio do Peixe (SP): Uma Contribuição ao Estudo da Neotectônica e da Morfogênese do Planalto Ocidental Paulista. Geociências 10, 6, 45-62, 2004.

FOSTER, M. A.; KESLEY, H. M. Knickpoint and knickzone formation and propagation, South Fork Eel River, northern California. Geosphere 8, 2, 403-416, 2012.

GOMES, C. J.; SILVA, R. G.; DANDERFER FILHO, A.; DI ALMEIDA, J. F. S.; PESSÔA, M. V. Aferição Múltipla De Modelos Geológico Estruturais por Meio Da Modelagem Física Analógica E Da Modelagem Estrutural Tridimensional: Um Exemplo Do Quadrilátero Ferrífero. Revista Brasileira de Geociências 35, 4, 525-534, 2005.

HACK, J.T. Stream profile analysis and stream-gradient index. Journal Res. United States Geological Survey 1, 421-429, 1973.

HAYAKAWA, Y. S.; OGUCHI, T. DEM-based identification of fluvial knickzones and its application to Japanese mountain rivers. Geomorphology 78, 90-106, 2006.

HARE, P. W.; GARDNER, I. W. Geomorphic indicators of vertical neotectonism along converging plate margins. Nicoya Peninsula, Costa Rica. In: MORISAWA M.; HACK J. T. (eds.). Tectonic Geomorphology. Proceedings of 15th Annual Binghamton Geomorphology Symposium, 1985.

HOWARD, A.D. Simulation model of stream capture. Geological Society of America Bulletin 82, 1355 1376, 1971.

HURTREZ, J.E.; SOL, C.; LUCAZEAU, F. Effect of drainage area on hypsometry from an analysis of small-scale drainage basins in the Siwalik Hills (central Nepal). Earth Surface Processes and Landforms 24, 799-808, 1999. 
LAVARINI, C.; MAGALHÃES JR, A. P.; OLIVEIRA, F. S.; CARVALHO, A.

KAFRI, U.; YECHIELI, Y. Groundwater Base Level Changes and Adjoining Hydrological Systems. Springer Berlin Heidelberg, Berlin, 2010.

KING, L.C. A Geomorfologia do Brasil Oriental. Revista Brasileira de Geografia 2, p. 3-121, 1956.

LANA, C. E. A Influência de Níveis de Base nas Características Morfossedimentares das Bacias dos Rios das Velhas e Jequitaí, MG. PhD Thesis, Universidade Federal de Ouro Preto, 2010.

LARUE, J. P. Longitudinal profiles and knickzones: the example of the rivers of the Cher basin in the northern French Massif Central. Proceedings of the Geologists' Association 122, 125-142, 2011.

LIPSKI, M. Tectonismo Cenozóico no Quadrilátero Ferrífero, Minas Gerais. MSc Thesis. Universidade Federal de Ouro Preto, 2002.

Loget, N., Driessche, J. V. D., 2009. Wave train model for knickpoint migration. Geomorphology 106, 376-382, 2009.

MAgAlHÃES JÚNIOR, A. P. Dinâmica Fluvial Cenozóica da Bacia do rio das Velhas na Região de Belo Horizonte-MG. MSc Thesis, Universidade Federal de Minas Gerais, 1993.

MAGALHÃES JÚNIOR, A.P.; BARROS, L.F.P.; RAPOSO, A.A.; CHEREM, L.F.S. Eventos deposicionais fluviais quaternários e dinâmica recente do vale do Rio Maracujá - Quadrilátero Ferrífero/MG. Revista Brasileira de Geografia Física 3, 78-86, 2010.

MAGALHÃES JÚNIOR, A.P.; BARROS, L.F.P.; RAPOSO, A.A.; CHEREM, L.F.S. Dinâmica Fluvial Quaternária do Rio Maracujá, Quadrilátero Ferrífero (MG). Revista Brasileira de Geomorfologia 13, 1, 3-14, 2012.

MAHER, E.; HARVEY, A. M.; FRANCE, D., The impact of a major Quaternary river capture on the alluvial sediments of a beheaded river system, the Rio Alias SE Spain. Geomorphology 84, 344-356, 2007.

MATHER, A.E. Adjustment of a drainage network to capture induced base-level change: an example from the Sorbas basin, SE Spain. Geomorphology 34, 271-289, 2000.

MOLIN, P.; PAZZAGLIA, F. J.; DRAMIS, F. Geomorphic expression of active tectonics in a rapidly-deforming forearc, Sila massif, Calabria, southern Italy. Am J Sci 304, 559-589, 2004.

NOCE, C. M. Geochronology of the Quadrilátero Ferrífero: A Review. Geonomos 8, 1, 15-23, 1995.

ÖZKAYMAK, Ç.; SÖZBILIR, H. Tectonic geomorphology of the Spildağı High Ranges, western Anatolia. Geomorphology, 173-174, 128-140, 2012.

PEDERSON, J. L.; TRESSLER, C. Colorado River long-profile metrics, knickzones and their meaning. Earth and Planetary Science Letters 345-348, 171-179, 2012.

PRINCE, P. S.; SPOTILA, J. A.; HENIKA, W. S. Stream capture as driver of transient landscape evolution in a tectonically quiescent setting. Geological Society of America 39, 823-826, 2011.

SAADI, A. Ensaio sobre a morfotectônica de Minas Gerais: tensões intra-placa, descontinuidades crustais e morfogênese. Thesis for full Professor, Universidade Federal de Minas Gerais, Belo Horizonte, 1991. SAlGADO, A.A.R.; VARAJÃO, C.A.C.; COLIN, F., BRAUCHER, R.; VARAJÃO, A.F.D.C.; NALINI JÚNIOR, H.A. Study of the erosion rates in the upper Maracujá Basin (Quadrilátero Ferrífero/MG, Brazil) by the in situ produced cosmogenic 10Be method. Earth Surface Processes and Landforms 32, 905-911, 2007.

SALGADO, A.A.R.; BRAUCHER, R.; VARAJÃO, C.A.C.; COLIN, F.; VARAJÃO, A.F.D.C.; NALINI JÚNIOR, H.A. Relief evolution of the Quadrilátero Ferrífero (Minas Gerais, Brazil) by means of 10Be cosmogenic nuclei. Zeitschrift für Geomorphologie 52, 317-323, 2008.

SALVANY, J. M., Tilting Neotectonics of the Guadiamar Drainage Basin, SW Spain. Earth Surf. Process. Landforms 29, 145-160, 2004.

SANTOS, M. C.,. Caracterização dos Depósitos Argilosos da Porção Centro-Sul do Sinclinal Moeda, Quadrilátero Ferrífero, MG: Macromorfologia, Micromorfologia, Cristaloquímica, Gênese e Considerações Industriais. PhD Thesis, Universidade Federal de Ouro Preto, 2003.

SANTOS, G. B. Geomorfologia Fluvial no Alto Vale do Rio das Velhas, Quadrilátero Ferrífero - MG: Paleoníveis Deposicionais e a Dinâmica Atual Minas Gerais. MSc Thesis, 2010. 
SARANGI, A.; BHATTACHARYA, A.K.; SINGH A.; SINGH A.K. Use of geographic information system (GIS) in assessing the erosion status of watersheds. Indian J Soil Conserv 29, 190-195, 2001.

SCHLUNEGGER, F.; SCHNEIDER, H. Relief-rejuvenation and topographic length scales in a fluvial drainage basin, Napf area, Central Switzerland. Geomorphology 69, 102-117, 2005.

SCHUMM, S.A. Evolution of drainage systems and slopes in badlands of Perth Amboy. Geological Society of America Bulletin 67, 597-646, 1956.

SEEBER, L.; GORNITZ V. River profiles along the Himalayan Arc as indicators of active tectonics. Tectonophysics 92, 335-367, 1983.

SILVA, R.G. Análise Estrutural e Modelagem Tectônica da região centro-sul do Sinclinal da Moeda, Quadrilátero Ferrífero, Minas Gerais. MSc Thesis, UFOP, 1999.

SMALL, R.J., The Study of Landforms: A Textbook of Geomorphology, second edition. Cambridge University Press, London, 1978.

STOKES, M.; MATHER, A. E.; HARVEY, A. M. Quantification of river-capture-induced base-level changes and landscape development, Sorbas Basin, SE Spain. Geological Society, London, Special Publications 191, 23-35, 2002.

STRAHLER, A.N. Hypsometric (area-altitude) analysis of erosional topography. Geol Soc Amer Bull 63, $1117-1141,1952$.

SUMMERFIELD, M.A. Global Geomorphology. Longman Scientific \& Technical, New York, NY, 1991.

TWIDALE, C.R. Analysis of Landforms. John Wiley \& Sons Australasia Pty Ltd, New York, NY, 1976.

TWIDALE, C.R. River patterns and their meaning. Earth-Science Reviews 67, 159-218, 2004.

VARAJÃO, C.A.C.; SALGADO, A.A.R.; VARAJÃO, A.F.F.C.; BRAUCHER, R.; COLIN, F.; NALINI JÚNIOR, H.A. Estudo da Paisagem do Quadrilátero Ferrífero (Minas Gerais, Brasil) por meio da mensuração das taxas de erosão (10Be) e da pedogênese. Revista Brasileira de Ciências do Solo 33, 1409-1425, 2009.

WALSH, S. J.; BUTLER, D. R.; MALANSON, G. P. An overview of scale, pattern, process relationships in geomorphology: a remote sensing and GIS perspective. Geomorphology 21, 183-205, 1998.

WEISSEL, J.K.; PRATSON, L.F.; MALINVERNO, A. The length-scaling properties of topography. $\mathbf{J}$ Geophys Res 99, 13997-14012, 1994.

WENZENS, E.; WENZENS, G. The influence of tectonics, sea-level fluctuations and river capture on the Quaternary morphogenesis of the semi-arid Pulpi Basin (southeast Spain). Catena 30, 283-293, 1997. WhITEMAN, C. A.; ROSE, J. Early-Middle Pleistocene Beheading of the River Thames. Géographie physique et Quaternaire 51, 3, 327-336, 1997.

ZAPROWSKI, B. J.; EVENSON, E. B.; PAZZAGLIA, F. J.; EPSTEIN, J. B. Knickzone propagation in the Black Hills and northern High Plains: A new perspective on the late Cenozoic exhumation of the Laramide Rocky Mountains. Geology 29, 547-550, 2001.

Submitted 5 july 2016

Accepted 5 august 2016 